Prepared in cooperation with the North Pacific Landscape Conservation Cooperative

\title{
Identifying Resource Manager Information Needs for the North Pacific Landscape Conservation Cooperative
}

Open-File Report 2014-1032 



\section{Identifying Resource Manager Information Needs for the North Pacific Landscape Conservation Cooperative}

By Andrea Woodward, Theresa Liedtke, and Karen Jenni

Prepared in cooperation with the North Pacific Landscape Conservation Cooperative

Open-File Report 2014-1032

U.S. Department of the Interior

U.S. Geological Survey 


\section{U.S. Department of the Interior \\ SALLY JEWELL, Secretary}

\section{U.S. Geological Survey \\ Suzette M. Kimball, Acting Director}

U.S. Geological Survey, Reston, Virginia: 2014

For more information on the USGS-the Federal source for science about the Earth,

its natural and living resources, natural hazards, and the environment-visit

http://www.usgs.gov or call 1-888-ASK-USGS

For an overview of USGS information products, including maps, imagery, and publications, visit $h$ ttp://www.usgs.gov/pubprod

To order this and other USGS information products, visit http://store.usgs.gov

Suggested citation:

Woodward, Andrea, Liedtke, Theresa, and Jenni, Karen, 2014, Identifying resource manager information needs for the North Pacific Landscape Conservation Cooperative: U.S. Geological Survey Open-File Report 2014-1032, 54 p., http://dx.doi.org/10.3133/ofr20141032.

ISSN 2331-1258 (online)

Any use of trade, firm, or product names is for descriptive purposes only and does not imply endorsement by the U.S. Government.

Although this information product, for the most part, is in the public domain, it also may contain copyrighted materials as noted in the text. Permission to reproduce copyrighted items must be secured from the copyright owner. 


\section{Contents}

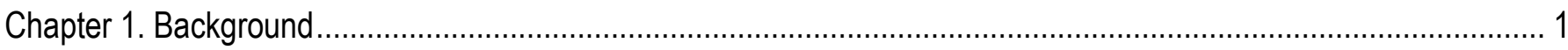

Description and Purpose of Landscape Conservation Cooperatives ................................................................ 1

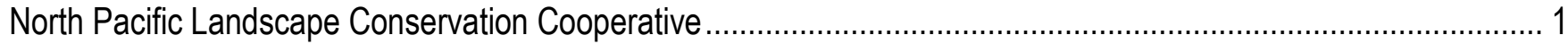

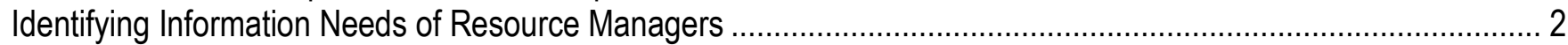

Decision Analytic Process .................................................................................................................. 3

Summary of Climate Change Predictions across the North Pacific Landscape Conservation Cooperative ............... 4

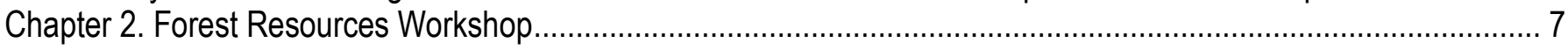

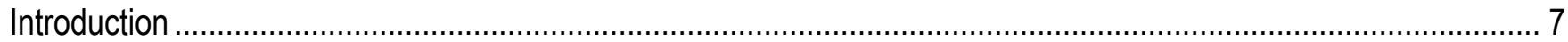

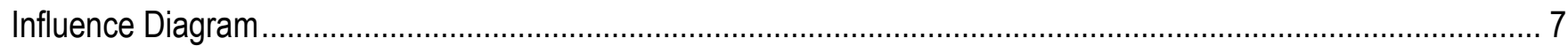

Valued Forest Resources and Characteristics ........................................................................................... 7

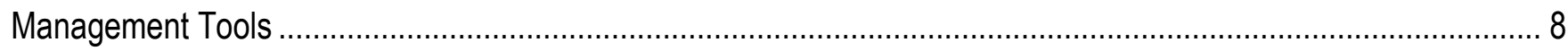

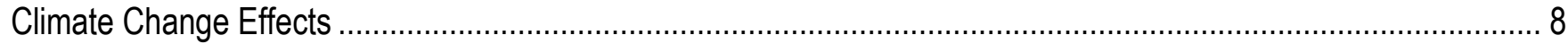

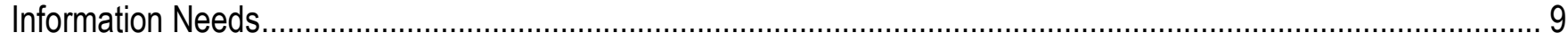

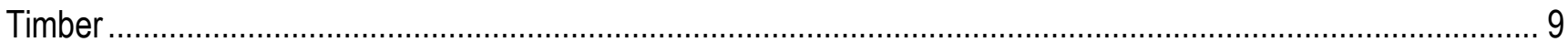

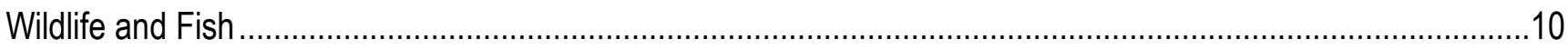

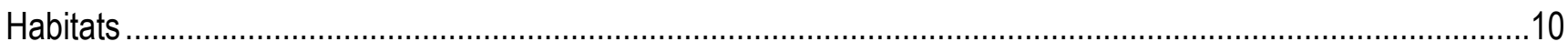

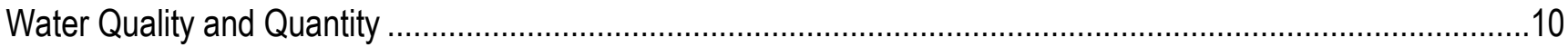

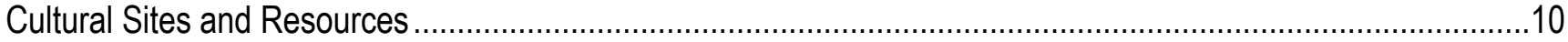

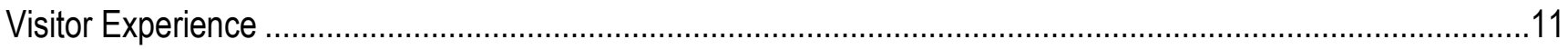

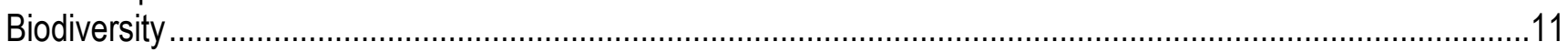

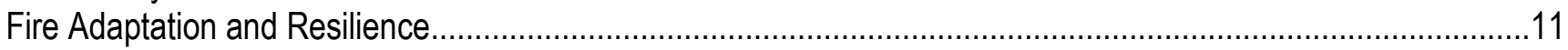

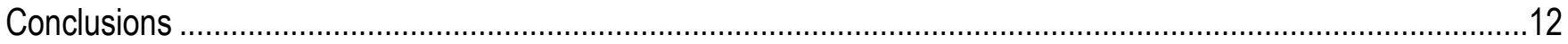

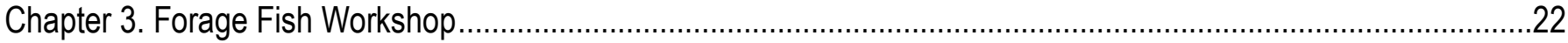

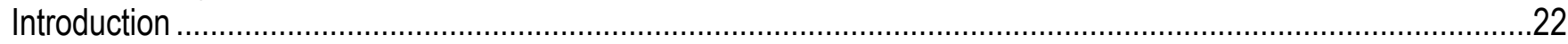

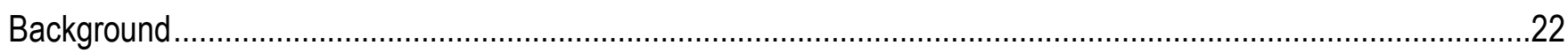

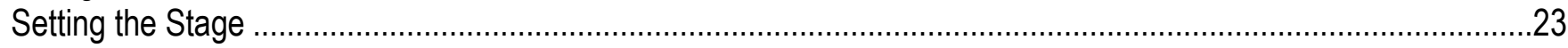

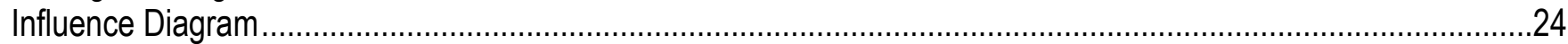

Forage Fish Resources within the North Pacific Landscape Conservation Cooperative ........................................24

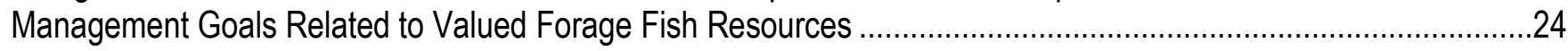

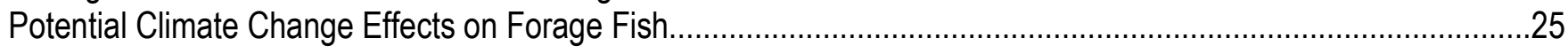

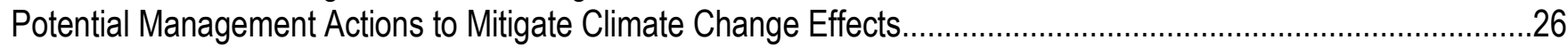

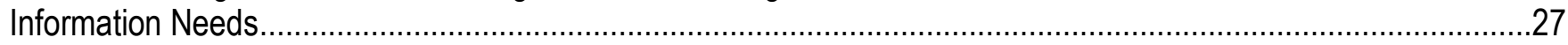

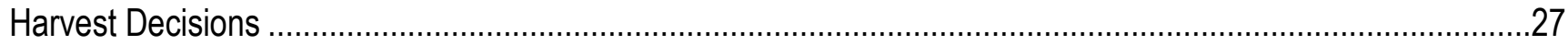

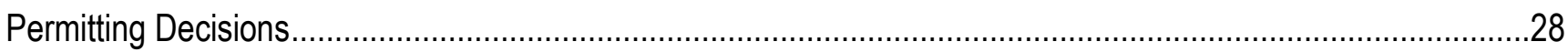

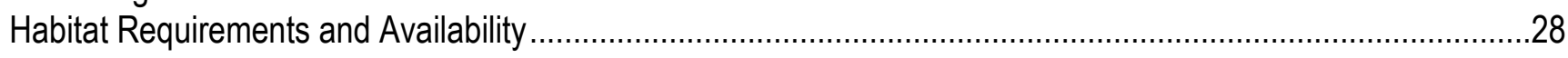

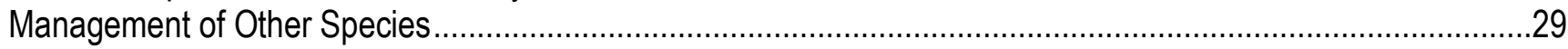

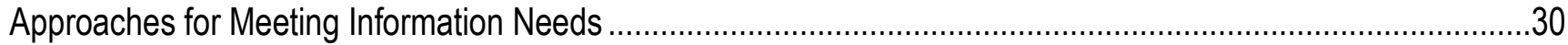

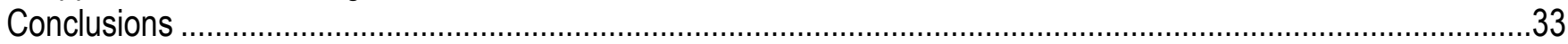

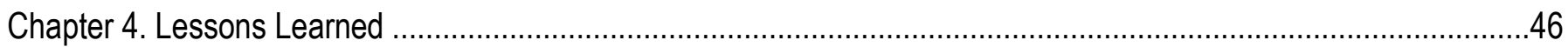

Unique Role of North Pacific Landscape Conservation Cooperative in Addressing Management Needs................46

Potential Role of Traditional Ecological Knowledge ..................................................................................4

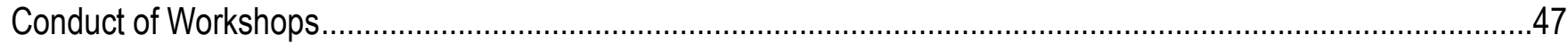


References Cited

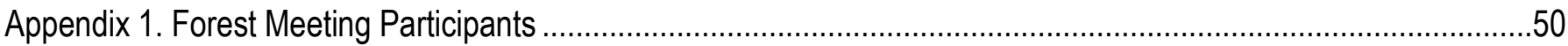

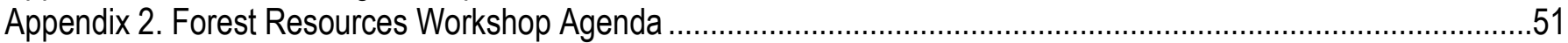

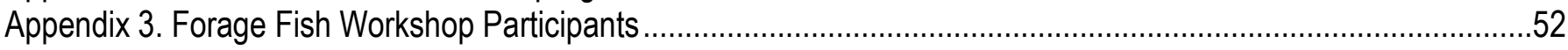

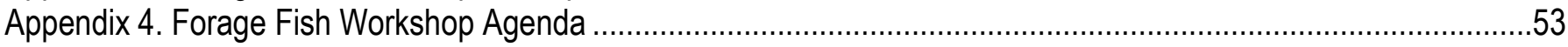

\section{Figures}

Figure 1.1. Elements of decisions made by resource managers as represented in Analytica ${ }^{\circledR}$ software.

Figure 1.2. Predicted change in temperature and precipitation (2041-2070) compared with the historical period (1971-2000) by latitude band, across the coverage area of the North Pacific Landscape Conservation Cooperative area.

Figure 2.1. Influence diagram showing effects of climate change on valued forest resources and on the effectiveness of management tools

Figure 2.2. Submodel for fire regime component of influence diagram created to describe effects of climate change on valued resources and management tools (fig.2.1)

Figure 2.3. Conceptual model of management objectives for forests .................................................................. 15

Figure 3.1. Influence diagram showing management tools and effects of climate change on valued forage fish (FF) resources.

Figure 3.2. Forage fish life (FF) history parameters submodel of the influence diagram created to describe effects of climate change on valued resources and management tools (fig. 3.1).....

Figure 3.3. Maintain healthy forage fish populations submodel of the influence diagram created to describe effects of climate change on valued resources and management tools (fig. 3.1).

Figure 3.4. Climate submodel of the influence diagram created to describe effects of climate change on valued resources and management tools (fig. 3.1)

Figure 3.5. Management decisions submodel of influence diagram created to describe effects of climate change on valued resources and management tools (fig. 3.1). 


\section{Tables}

Table 2.1. Valued forest resources and forest characteristics grouped by categories............................................. 16

Table 2.2. Management tools available to respond to climate change effects ...................................................... 17

Table 2.3. Information required by resource managers to use management tools to meet management goals for timber resources

Table 2.4. Information required by resource managers to use management tools to meet management goals for wildlife and fish resources.

Table 2.5. Information needs required by resource managers to use management tools to meet management goals for habitat

Table 2.6. Information required by resource managers to use management tools to meet management goals for water quality and quantity

Table 2.7. Information needs required by resource managers to use management tools to meet management goals for cultural sites and resources

Table 2.8. Information required by resource managers to use management tools to meet management goals for visitor experience

Table 2.9. Information required by resource managers to use management tools to meet management goals for biodiversity......

Table 2.10. Information required by resource managers to use management tools to meet management goals for achieving fire adaptation and resilience.

Table 3.1. Forage fish resources within the North Pacific Landscape Conservation Cooperative (NPLCC). 39

Table 3.2. Management goals for forage fish 40

Table 3.3. Potential management actions at the landscape level. 41

Table 3.4. Potential management actions that directly affect the landscape ....................................................... 42

Table 3.5. Potential management actions that apply to other types of decisions ................................................... 42

Table 3.6. Management goals, potential tools or decisions, and information needs for harvest decisions .................. 43

Table 3.7. Management goals, potential tools or decisions, and information needs for permitting decisions .............. 43

Table 3.8. Management goals, potential tools or decisions, and information needs for decisions about habitat protection

Table 3.9. Management goals, potential tools or decisions, and information needs for management of other species 


\section{Conversion Factors and Datum}

\section{Conversion Factors}

SI to Inch/Pound

\begin{tabular}{|c|c|c|}
\hline Multiply & By & To obtain \\
\hline \multicolumn{3}{|c|}{ Area } \\
\hline square kilometer $\left(\mathrm{km}^{2}\right)$ & 247.1 & acre \\
\hline
\end{tabular}

Temperature in degrees Celsius $\left({ }^{\circ} \mathrm{C}\right)$ may be converted to degrees Fahrenheit $\left({ }^{\circ} \mathrm{F}\right)$ as follows: ${ }^{\circ} \mathrm{F}=\left(1.8 x^{\circ} \mathrm{C}\right)+32$.

Temperature in degrees Fahrenheit $\left({ }^{\circ} \mathrm{F}\right)$ may be converted to degrees Celsius $\left({ }^{\circ} \mathrm{C}\right)$ as follows: ${ }^{\circ} \mathrm{C}=\left({ }^{\circ} \mathrm{F}-32\right) / 1.8$.

\section{Datum}

Horizontal coordinate information is referenced to the North American Vertical Datum of 1988 (NAVD 88). 


\title{
Identifying Resource Manager Information Needs for the North Pacific Landscape Conservation Cooperative
}

\author{
By Andrea Woodward ${ }^{1}$, Theresa Liedtke ${ }^{1}$, and Karen Jenni²
}

\section{Chapter 1. Background}

\section{Description and Purpose of Landscape Conservation Cooperatives}

Landscape Conservation Cooperatives (LCCs) are a network of 22 public-private partnerships, defined by ecoregion, that share and provide science to ensure the sustainability of land, water, wildlife and cultural resources in North America. LLCs were established by the U.S. Department of Interior (DOI) in recognition that response to climate change must be coordinated on a landscape-level basis because important resources, ecosystem processes and resource management challenges extend beyond national wildlife refuges, Bureau of Land Management lands, national parks, and even international boundaries. Therefore, DOI agencies must work with other Federal, State, Tribal (U.S. indigenous peoples), First Nation (Canadian indigenous peoples), and local governments, as well as private landowners, to develop landscape-level strategies for understanding and responding to climate change.

\section{North Pacific Landscape Conservation Cooperative}

The North Pacific LCC (NPLCC) covers the range of the Pacific coastal temperate rainforest, including an area of $528,360 \mathrm{~km}^{2}$ spanning 22 degrees of latitude from the Kenai Peninsula, Alaska, to Bodega Bay, California. The coverage area includes parts of four States and one Canadian province. It extends from alpine areas at the crest of coastal mountains across subalpine, montane, and lowland forests to the nearshore marine environment. This wide range of latitudes and elevation zones; terrestrial, freshwater, and marine habitats; and complex jurisdictional boundaries hosts a diversity of natural resources and their corresponding management issues.

The specific mission of the NPLCC is to promote "development, coordination, and dissemination of science to inform landscape level conservation and sustainable resource management in the face of a changing climate and related stressors" (North Pacific Landscape Conservation Cooperative, undated). The strategy for identifying, prioritizing and addressing science needs is the responsibility of the Science and Traditional Ecological Knowledge (S-TEK) Subcommittee, which established the following guiding principles in the NPLCC Strategy for Science and Traditional Ecological Knowledge, 2013-2016 (S-TEK Strategy, Jenni and others, 2012):

\footnotetext{
${ }^{1}$ U.S. Geological Survey.

${ }^{2}$ Insight Decisions, LLC.
} 
- Focus on helping managers understand the availability and effectiveness of adaptation and mitigation response actions.

- Focus on facilitating coordination, collaboration, and capacity building, and on developing or assisting with tools to assist decision-makers.

- Identify and promote opportunities to use Traditional Ecological Knowledge (TEK) to inform partner and stakeholder decisions.

- Promote and facilitate understanding of the connections and interactions between ecosystems. These principles emphasize the importance of conducting activities that are immediately relevant to resource managers.

In addition to guiding principles, the S-TEK committee also identified five priority topics to be addressed in the first 4-year strategic plan:

1. Effects of hydrologic regime shifts on rivers, streams, and riparian corridors;

2. Effects of change in air temperature and precipitation on forests;

3. Effects of changes in sea levels and storms on marine shorelines, the nearshore, and estuaries;

4. Effects of the changes in the hydrologic regime on anadromous fish; and

5. Invasive species, diseases, pests, and their effects on biological communities.

\section{Identifying Information Needs of Resource Managers}

As evidenced by the guiding principles presented in the S-TEK Strategy (Jenni and others, 2012), identifying and responding to the needs of resource managers is key to the success of the NPLCC. To help achieve the goals of the NPLCC, the U.S. Geological Survey (USGS) organized two workshops with resource managers to identify management information needs relevant to two of the priority topics identified in the S-TEK Strategy, forests and forage fish.

One workshop focused on forests, the second priority topic listed in the NPLCC Science Strategy (see list in section, "North Pacific Landscape Conservation Cooperative"). The second workshop focused on forage fish (defined as small pelagic fish preyed on by larger fish, seabirds and mammals). Forage fish was chosen as a workshop theme before the priority list was finalized, but forage fish are connected to several of the identified priority topics (specifically, hydrology, sea level, anadromous fish, and invasive species) as described in chapter 4.

The workshops were structured to answer the following questions about each priority topic:

- What are the valued resources, services, and management goals?

- How is climate change anticipated to affect valued resources and goals? What are the priority vulnerabilities to climate change?

- What adaptation strategies may managers use in response to anticipated changes in resources due to climate change?

- What information is needed to inform and employ management responses?

Workshops were conducted in 1 day and were professionally facilitated using decision analytic techniques (Keeler and others, 2004). In addition to a narrative account and tables of lists, the workshop discussions were recorded conceptually using influence diagrams describing management tools, valued resources, and potential climate change effects. 


\section{Decision Analytic Process}

Decision analysis (DA) is a framework and a process used to formally structure the decisionmaking process, and consists of relevant philosophy, theory, methodology, and professional practice (Keefer and others, 2004). Decision analysis includes procedures, methods, and tools to help decision makers identify, clearly represent, and formally assess important aspects of a decision in order to recommend a course of action.

The influence diagram is an important tool often used during decision analysis to structure and to communicate the various components of a decision situation. Often used as the first step towards analyzing decision options, the influence diagram is a simple visual representation used to identify and to display the essential elements of a decision problem (Howard and Matheson, 2005; Pearl, 2005). Elements include objectives (what people would like to achieve in the particular situation being evaluated), types of decisions and decision points (what actions can be taken to try to bring about more desirable outcomes), and uncertainties (factors, events, and processes that affect outcomes but that are outside the control of decision-makers, and the relationships between all three components). The influence diagram is a high-level conceptual model from which a detailed quantitative model can be built. We do not intend to develop quantitative models, rather we used influence diagrams to describe the decision context, management actions, and desired outcomes for the group of natural resources addressed during each workshop as a means of conceptualizing the issues and creating consensus.

Influence diagrams were created using Analytica ${ }^{\circledR}$ software developed by Lumina Decision Systems ${ }^{\circledR}$. In this format (fig. 1.1), rectangles denote decision points (variables or factors that the decision-maker can modify), ovals denote uncertainties (variables or factors about which information is incomplete and that cannot be controlled directly), hexagons denote objectives or measures of satisfaction and what managers want to maximize, rounded rectangles denote general variables whose values are determined by the quantities on which they depend, and arrows denote influences of one variable on another. The influence indicated by arrows is not necessarily causal or related to a material flow; rather, the arrow denotes when knowledge about one variable is relevant to determining the value of another variable. Analytica ${ }^{\circledR}$ software also enables the user to build submodels to add detail to particular sections of the model. 


\section{Summary of Climate Change Predictions across the North Pacific Landscape Conservation Cooperative}

Both workshops focused on decisions resource managers need to make to maximize efforts to meet their management objectives, with a particular focus on how changes in climate will affect their ability to meet those objectives, and the types and effectiveness of available resource management actions. Forest managers are experienced in planning ahead by many decades because even private foresters, who value short rotations, typically use harvest rotations ranging from 40 to 60 years (Partridge and MacGregor, 2007). For forage fish, most decisions are currently made over shorter time frames, when climate change can have a more acute influence the resource. To set the context for considering climate change effects on natural resources, we summarized the predicted effects of climate change on temperature, precipitation, and ocean conditions in the NPLCC region. These three factors are fundamental drivers of other relevant environmental influences.

Predictions of future changes in temperature and precipitation were customized for the NPLCC (Darrin Sharp, Oregon Climate and Research Institute, written commun.) and describe the average forecast of six general circulation models summarized by latitude band. Temperature is predicted to increase throughout the NPLCC and during all seasons (fig. 1.2), with the greatest increases (greater than $5^{\circ} \mathrm{C}$ ) predicted for the winter in Alaska, and for the summer at southern latitudes. Precipitation is predicted to increase in all seasons at the northern end of the NPLCC by 10-20 percent, and to decrease in all seasons at the southern end, with the largest decrease of about 15 percent in the summer. These projections suggest that fundamental environmental drivers, such as moisture availability, evapotranspiration, and hydrologic regime, are expected to change substantially (Mote and others, 2003; Littell and others, 2010), and will vary across the NPLCC.

Workshop participants were informed that anticipated changes in the Northeast Pacific Ocean marine system, owing to climate change include increased sea-surface temperature, changes in the location and timing of upwelling, ocean acidification, rising sea level, and increased local storm activity, which will increase the intensity of wave action (Nicholas Bond, Washington State Climatologist, oral commun.; Wang and others, 2010). Forecasting for small spatial scales and short temporal scales is challenging because of the natural variability in ocean climate conditions that typically vary on the decadal scale. 

Management actions
Information needs
Management goals

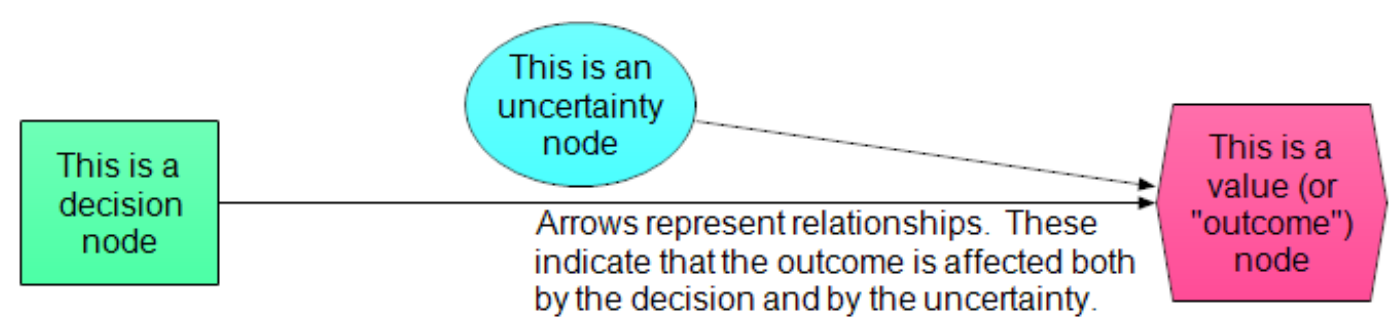

This is a "general"

node, often used

to represent

calculated values

\section{This is a \\ submodel}

Figure 1.1. Elements of decisions made by resource managers as represented in Analytica ${ }^{\circledR}$ software. 

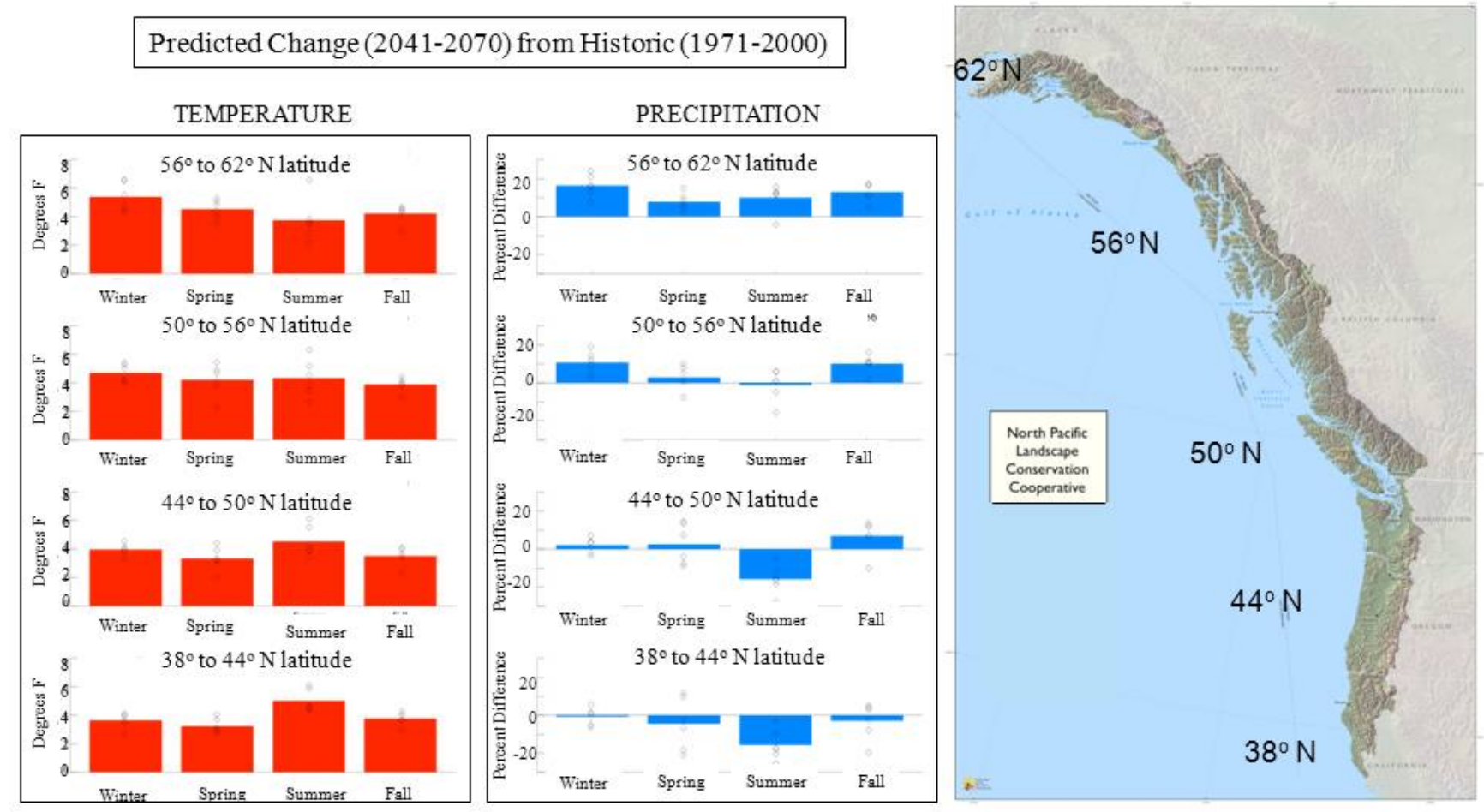

Figure 1.2. Predicted change in temperature and precipitation (2041-2070) compared with the historical period (1971-2000) by latitude band, across the coverage area of the North Pacific Landscape Conservation Cooperative area. Predictions are the average outputs of six general circulation models. 


\section{Chapter 2. Forest Resources Workshop}

\section{Introduction}

The workshop to identify the information needs of forest managers was held in Seattle, Washington, on November 20, 2012. Thirteen people attended, including two people by phone, representing the following agencies and Tribes, with some people representing more than one entity (see appendix 1 for a list of participants and affiliations):

- U.S. Forest Service, Alaska Rainforest Center

- U.S. Forest Service, Mount Baker-Snoqualmie National Forest, Washington

- U.S. Forest Service, Pacific Northwest Research Station

- U.S. Forest Service, Six Rivers National Forest, California

- University of Washington Climate Impacts Group

- Inter-tribal Timber Council

- Quinault Tribe

- British Columbia Ministry of Forests, Lands and Natural Resource Operations

- National Park Service, Olympic National Park

- National Park Service, Redwoods National Park

- U.S. Fish and Wildlife Service, Washington Fish and Wildlife Office

- North Pacific Landscape Conservation Cooperative

- U.S. Geological Survey, Forest and Rangelands Ecosystem Science Center

The workshop was organized by Andrea Woodward and facilitated by Karen Jenni (Insight Decisions) using the principles of decision analysis (Keefer and others, 2004) described in chapter 1. The overarching goal was to determine what information managers need in order to address climate-change effects given management goals, high-priority resources, and available management tools. The workshop agenda is shown in appendix 2.

\section{Influence Diagram}

Influence diagrams were used as a framework for identifying management tools, valued resources and forest characteristics, and potential effects of climate change on key ecosystem processes and components; and for illustrating some of the key relationships (fig. 2.1). Additional detail was developed in submodels for topics in darker blue boxes (for example, fig. 2.2). The influence diagram was used primarily to record and organize a wide-ranging group discussion, and is not intended to be a comprehensive representation of all possible factors and relationships.

\section{Valued Forest Resources and Characteristics}

Categories of valued forest resources and characteristics are shown in hexagons along the right edge of the influence diagram, with examples of each category in boxes to the immediate left of each category (fig. 2.1). A complete list of valued forest resources identified during the workshop is shown in table 2.1. The list of resources and services supporting Tribal and First Nations ways of life is a subset of resources with non-market value. Valued resources varied by agency, reflecting each mandate, but the valued ecological services and desired characteristics were more universal. 
The image of forest management that emerged from the workshop is one of a multi-objective optimization problem where some objectives conflict with others (fig. 2.3). Specifically, forest managers are faced with the challenge of extracting physical resources and providing non-extracted resources and services to the public while doing so may alter the desired forest characteristics needed for forests to provide those resources and services. Moreover, priorities for goods and services vary among agencies, and the decisions of one agency may affect the ability of another agency to achieve its specific goals. Finally, climate change, increases in other stressors, and potential shifts in the social, economic, and cultural context of decisions introduce additional risk to management decisions. For example, the establishment of a carbon tax could greatly affect forest practices. Therefore, management decisions are made in an increasingly uncertain environment where the consequences of decisions may not materialize for decades.

\section{Management Tools}

Management tools are depicted as rectangles, mostly located on the left edge of the influence diagram (fig. 2.1). A complete list of potential management tools identified during the workshop is shown in table 2.2, grouped according to whether they are (1) manipulative of the environment, (2) nonmanipulative activities and decisions that can be taken within agencies, or (3) activities that attempt to influence the decisions of others. Agencies differ in their legal authority to use these tools. The U.S. Forest Service (USFS) and National Wildlife Refuge System (NWRS) managers generally have the greatest capability to use manipulative tools; National Park Service (NPS) relies most on nonmanipulative activities conducted within the agency; Tribes and First Nations rely most on influencing others; and U.S. Fish and Wildlife Service (USFWS) staff concerned with endangered species are able to influence others through regulations and habitat prescriptions.

\section{Climate Change Effects}

As summarized in chapter 1, climate projections for the NPLCC lead to predictions about temperature and precipitation at various time intervals in the future. Using the influence diagram structure, workshop participants identified the specific climate variables most important to forestswind, storminess, distribution of freezing conditions, snow regime, evapotranspiration rates, relative humidity, solar radiation, and fog (especially in northern California). Changes in these factors, in turn, will directly affect plants and animals (that is, growth rate, mortality), growing conditions (that is, growing season length, water availability, phenology), disturbances (that is, fire regime, invasive species spread and success, insect and disease spread and success), as well as infrastructure needed for management (that is, access for management activities). Changes in fire regime were thought to be especially important and will be affected by amount and seasonality of precipitation, and changes in temperature and snow regimes. Characteristics of fire regime that are expected to be affected include fire behavior, intensity, severity, frequency, size and seasonality. Change in fire regime will have feedback effects on atmospheric carbon dioxide and snow regime. 


\section{Information Needs}

Information needs were discussed in detail for examples of each category of valued forest resources and characteristics. As a first attempt at prioritizing information needs, workshop participants made quick assessments of the state of existing knowledge using a 1-4 scale (where $1=$ nothing is known, and $4=$ "enough" is known such that additional work on reducing uncertainty in that area should not be a priority). These values are listed in tables 2.3-2.10. Several overarching questions and information needs emerged that apply to all categories of forest resources and services. These questions are especially appropriate for NPLCC to consider because they ask for information at a scope and scale that NPLCC is uniquely mandated to address:

- Can / how can we maintain functional forests on the landscape given multiple management entities (both private and multiple public agencies) with different objectives and mandates?

- How does the existence of overlapping jurisdictions and multiple management entities with responsibilities for the same resource, or with responsibilities that affect the same resource, affect the ability of any one management entity to meet their management objectives?

- What is an appropriate temporal planning horizon for any of these decisions?

- What is the appropriate spatial scale to consider while planning for any of these decisions? Over what spatial extent should goals for ecological characteristics be set and evaluated?

- What will be the effects of specific adaptation and mitigation responses under different climate scenarios (including unanticipated changes)?

- What monitoring activities should be undertaken to enable adaptive management?

Tools for managing each of the valued resources, as well as the information needed to support decisions regarding the use of those tools are summarized in the eight subsections that follow.

\section{Timber}

Participants identified planting of species and genotypes that will be productive under future climate as one of the most important timber-related management actions with potential to confront climate change (table 2.3). Stand density control, including the selection of species for harvest, also will be a more important activity under changing climate than at present (2013) and will be needed to increase forest resilience. Harvest plans also are expected to change, but specific change depends on climate effects - cut levels could be decreased and (or) rotation length increased if growth rates decrease, and (or) there could be a short-term increase in cut levels and a sustained decrease in rotation length to address uncertainty, economic considerations, and the expected high rate of climate change. These decisions are occurring in the economic context of timber companies that have become relatively small, and tree production and mills that have become separate businesses. Changes also will be needed to update access and transportation infrastructure design and maintenance to address the direct effects of climate change, such as changing hydrology. Other management activities that have low climate relevance, primarily because managers felt they are likely to remain infeasible at large spatial scales, include fertilization, chemical control of competing vegetation, and treatments of pests. 


\section{Wildlife and Fish}

Actions to manage priority fish and wildlife species in the face of climate change include activities that directly address habitat, other stressors, and endangered species. Information needs relate to determining what constitutes habitat by characterizing currently occupied habitats and understanding the flexibility of habitat requirements (table 2.4). After habitat requirements are understood, managers need to know where those habitats exist currently, where they will migrate to, and at what rate. Functional characteristics, such as connectivity and location of barriers, also are important for determining a habitat protection strategy, including changing forest management practices to enhance habitat. Habitat distribution and abundance also will influence direct actions regarding particular species (for example, reintroduction, assisted migration, captive breeding, and species selection). It also may be worthwhile to better understand and to address stressors other than climate change, such as predators and harvest levels, to maintain viable populations of priority species. Finally, public education and outreach are a means of minimizing adverse effects on species of interest.

\section{Habitats}

Maintaining an adequate inventory of habitats under future climate conditions somewhere on the landscape is vital to maximizing biodiversity and populations of priority species. Information required to achieve this goal includes an inventory of current habitats, their health and diversity, and forecasts of where those habitats can occur in the future (table 2.5). Considerations must include the effects of other stressors, which may present a more immediate threat and which are predicted to become more important as climate change increases. Moreover, it is important to consider as yet unanticipated consequences of management actions.

\section{Water Quality and Quantity}

Questions related to the effects of climate change on hydrology, such as changes in timing of peak flows, are relevant to forest management and were of interest to the workshop participants. These questions will be addressed in future workshops, and, therefore, were not a focus of discussion. The other water-quality and quantity information needs most directly relevant to forest management concern how forest characteristics and management practices affect water quality and fish habitat (table 2.6).

\section{Cultural Sites and Resources}

Laws regarding rights of Tribes and First Nations vary among Canada, Alaska, and the continental United States; only one perspective from the continental United States was represented at the workshop. Nevertheless, workshop participants recognized that the fundamental challenge of protecting the rights of indigenous peoples who have resource-based and place-based interests outside of present reservations spans these jurisdictions. Besides being vulnerable to potentially competing priorities of various agencies, some culturally valued characteristics of these places (for example, fish, wildlife, and plants are aspects of ceremonial places) also are potentially threatened by climate change. A major issue for Tribes and First Nations is obtaining access to and use of culturally important sites, which requires including social and cultural considerations in plans for addressing climate change (table 2.7). For example, the ability of indigenous peoples to engage in traditional activities is limited by the importance society places on the non-market value compared to the market value of resources, the restrictions the Endangered Species Act imposes on activities, the fire policy of the U.S. Forest Service, and societal attitudes toward allowing temporary exclusive use of ceremonial areas. 


\section{Visitor Experience}

Among the agencies represented, managing for visitor experience may be most important to the National Park Service. Concerns include management of infrastructure that enables access and safety (table 2.8). There also is a need to anticipate changes so they can be interpreted for the purposes of education and managing visitor expectations.

\section{Biodiversity}

We did not have sufficient time to discuss this topic in depth during the workshop. Strategies for maintaining biodiversity focus on managing forests to maintain a diversity of habitats, either through protection or manipulation (tables 2.5 and 2.9). Although it is not possible to address all species individually (Caro, 2010; U.S. Fish and Wildlife Service, 2012), to the extent that priority species identified by criteria under wildlife and fish (described in section, "Wildlife and Fish") function as surrogate species (U.S. Fish and Wildlife Service, 2012), the actions regarding wildlife and fish (described in section, "Wildlife and Fish"), will protect a larger suite of species and biodiversity more generally. Consequently, information needs identified in table 2.4 also cover information needs regarding biodiversity.

\section{Fire Adaptation and Resilience}

Restoring fire-adapted forested ecosystems was one of the key management objectives identified during the workshop. After years of forest fire suppression, forests are thought to have a significant "disturbance deficit" represented by artificially high level of fuels. This makes forests vulnerable to catastrophic fires under current climate (Stephens and others, 2012), and the threat is expected to increase under predicted temperature and precipitation trends (McKenzie and others, 2004; Littell and others, 2010. Potential responses include fuel treatments or letting fires burn if they do not threaten human infrastructure. Selective harvest by species for stand-density control also can decrease fire intensity, such as harvesting Douglas-fir (Pseudotsuga menziesii) and grand fir (Abies grandis) from the forest understory and allowing ponderosa pine (Pinus ponderosa) to thrive. Harvest decisions are complicated by the differing incentives among landowners. Whereas the USFS is interested in maximizing resilience (U.S. Department of Interior and others, 2001), private landowners need to cut trees to maintain financial liquidity. Time constraints prevented workshop participants from identifying specific information needs to support decision-makers related to creating fire-resilient or fire-adapted forests (table 2.10). However, many information needs are being addressed by the USFS (Luce and others, 2012) and State agencies responsible for forest management. 


\section{Conclusions}

Simultaneously meeting the multiple objectives for extractive and non-extractive resources society expects of forests while maintaining characteristics that impart functionality is a complicated endeavor under a steady climate. Climate change only increases the uncertainty surrounding management decisions regarding long-lived trees - decisions that necessarily have long-term consequences. Moreover, social, economic, and cultural priorities are expected to change along with environmental drivers, and the effects of these changes are expected to become increasingly difficult to predict. The management environment includes multiple entities with differing incentives and legal mandates, especially between the private and public sectors. The extent of drivers, disturbances, and ecological linkages is such that resources occurring in one ownership are potentially affected by decisions made in another ownership. This is especially true of migratory species, species with large home ranges, as well as Tribal and First Nations cultural resources and reserved rights, which are almost entirely vulnerable to decisions made by others. This situation calls for better predictions of environmental change and better collaboration among forest managers across large spatial extents.

Although the workshop did not result in a comprehensive prioritization of all possible information needs due to time constraints, some important information needs are clear. Topics rated as having the greatest knowledge deficit have to do with where habitats will change and move; and how restoration methods and activities will be affected owing to climate change. These topics were identified for wildlife and fish, but are related to the need for knowledge of range shifts of tree species. Distribution of tree species largely will determine the distribution of other vegetation types, wildlife habitat, and occurrence of other forest resources with market and non-market value. Additionally, predictions are needed for economic factors affecting the future value of various forest products. Workshop participants also noted that the full direct and indirect effects of management actions often are poorly understood. Improving this understanding becomes even more critical given the additional uncertainty about environmental changes, which may magnify the unanticipated side-effects of management actions. 


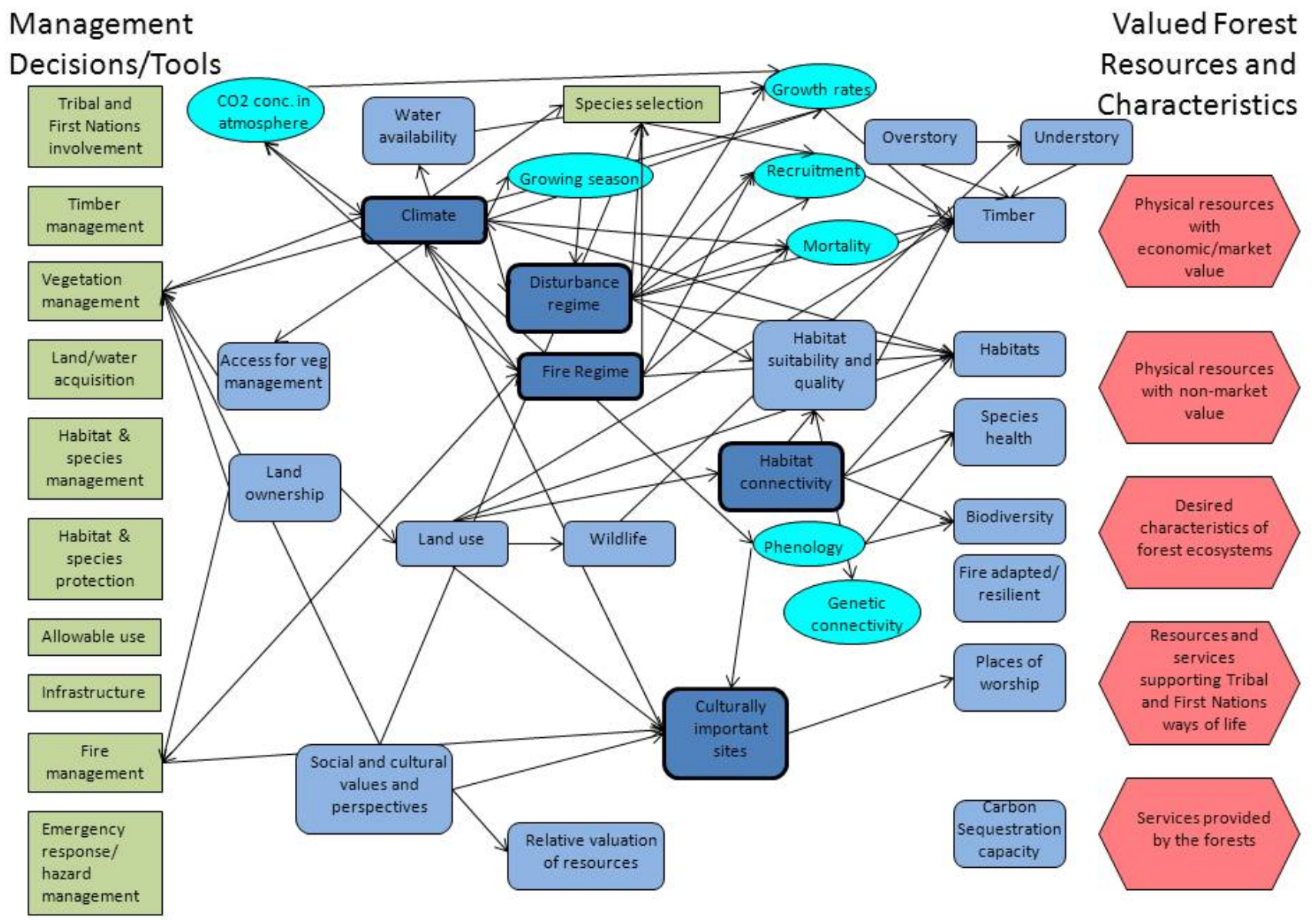

Figure 2.1. Influence diagram showing effects of climate change on valued forest resources and on the effectiveness of management tools. Ovals indicate chance variables, rounded rectangles indicate point or interim values, dark rounded rectangles indicate topics with submodels, rectangles indicate management tools, and hexagons indicate categories of valued forest resources and characteristics. Arrows indicating relationships among elements are meant to illustrate priority relationships. The diagram summarizes the workshop discussion and is not intended to be a comprehensive representation of all possible factors and relationships. 


\section{FIRE REGIME SUBMODEL}

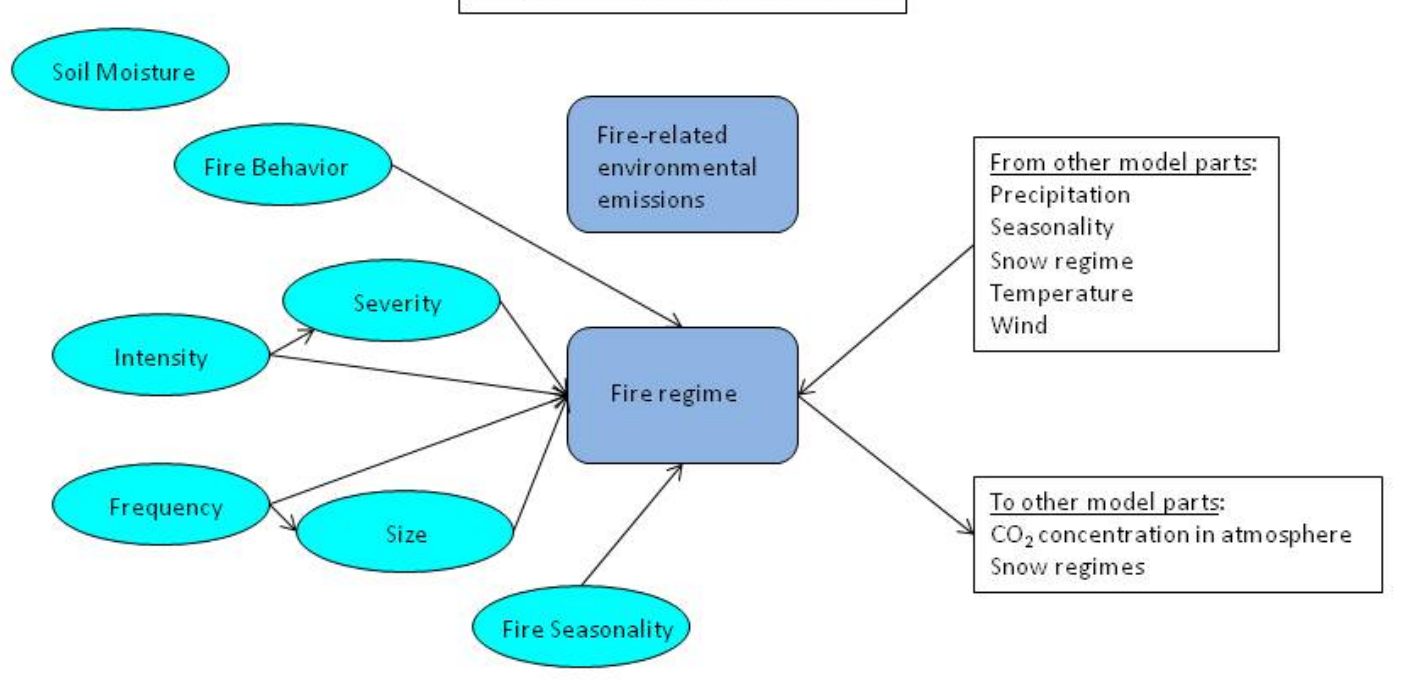

Figure 2.2. Submodel for fire regime component of influence diagram created to describe effects of climate change on valued resources and management tools (fig.2.1). Relationships indicated among elements are mean to illustrate priority relationships rather than be comprehensive. 


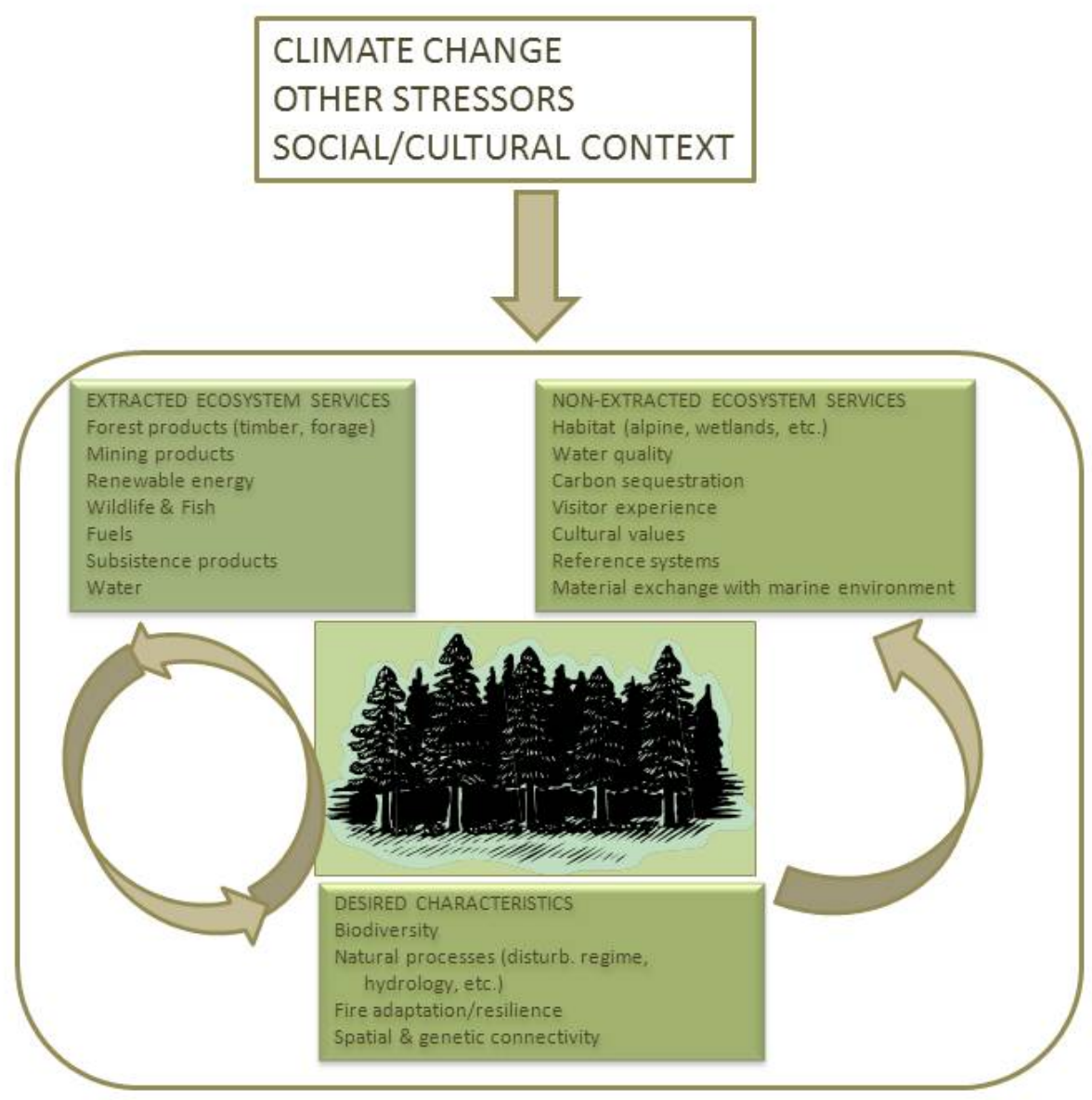

Figure 2.3. Conceptual model of management objectives for forests. 
Table 2.1. Valued forest resources and forest characteristics grouped by categories.

\begin{tabular}{|c|c|}
\hline Valued resource category & Items \\
\hline $\begin{array}{l}\text { Physical resources with economic/market } \\
\text { value }\end{array}$ & $\begin{array}{l}\text { - Forest Products - timber, forage, understory (for example, berries), } \\
\text { overstory (for example, boughs, cones, lichens) } \\
\text { - Mining products — sand, gravel, minerals, gold } \\
\text { - Renewable energy resources (biofuels, biomass, pellet productions) } \\
\text { - Wildlife and fish } \\
\text { - Foods } \\
\text { - Fuels } \\
\text { - Medicines } \\
\text { - Infrastructure and private property interests }\end{array}$ \\
\hline Physical resources with non-market value & 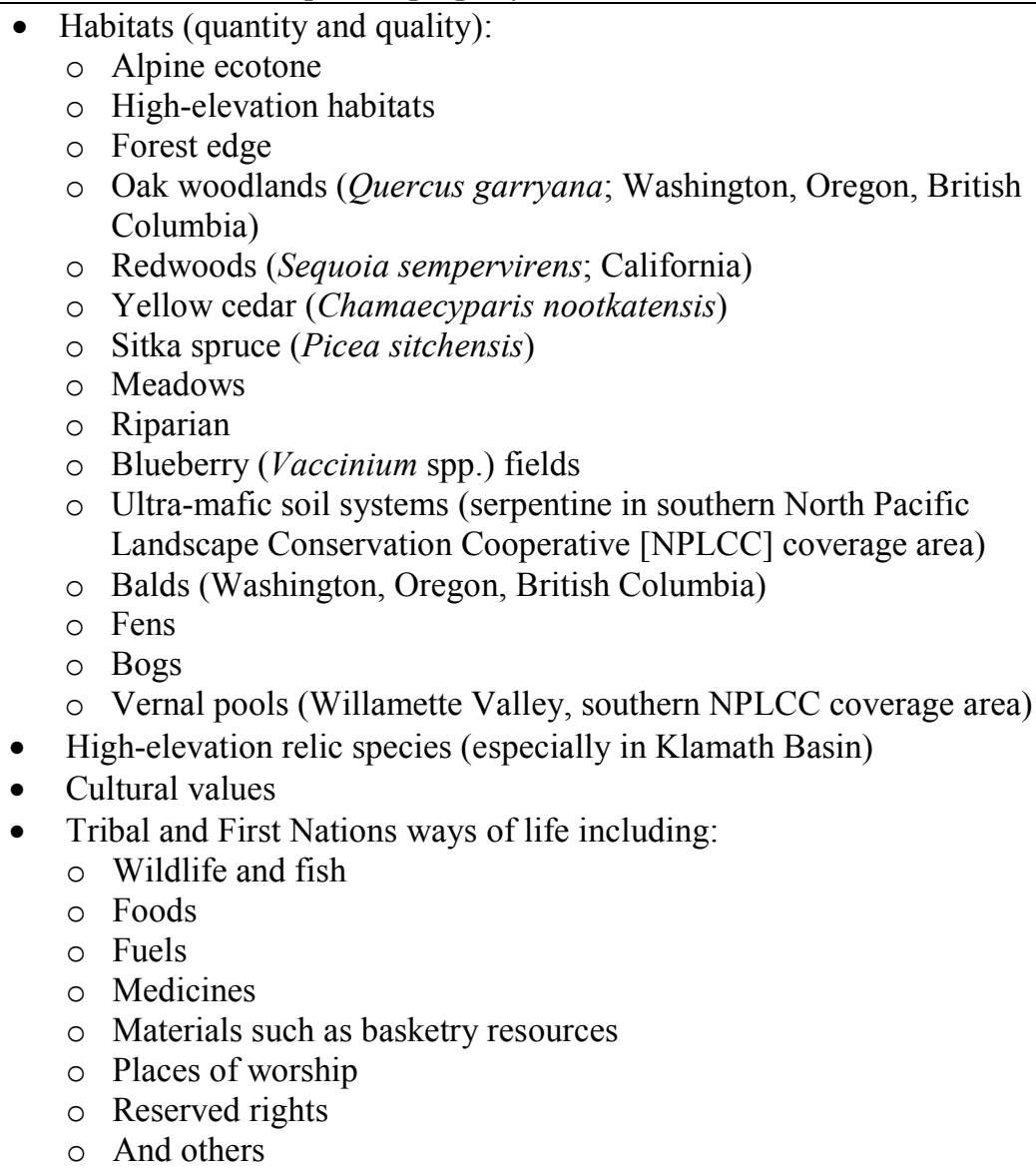 \\
\hline Desired characteristics of forest ecosystems & $\begin{array}{l}\text { - } \text { Biodiversity } \\
\text { - } \quad \text { Fire-adapted, fire resilient } \\
\text { - } \quad \text { Watural processes } \\
\text { - Connectivity of habitats (for various wildlife species, especially } \\
\text { - } \quad \text { Greatened, old-growth dependent and early seral) } \\
\quad \text { Gennectivity among populations }\end{array}$ \\
\hline $\begin{array}{l}\text { Resources and services supporting Tribal } \\
\text { and First Nations ways of life }\end{array}$ & $\begin{array}{l}\text { - Cultural values } \\
\text { - Tribal and First Nations ways of life including: } \\
\circ \text { Wildlife and fish } \\
\circ \text { Foods } \\
\circ \text { Fuels } \\
\circ \text { Medicines } \\
\end{array}$ \\
\hline
\end{tabular}




\begin{tabular}{|c|c|}
\hline Valued resource category & Items \\
\hline & $\begin{array}{ll} & \text { Materials, such as basketry resources } \\
\circ & \text { Places of worship } \\
\circ & \text { Reserved rights } \\
\circ & \text { And others } \\
\end{array}$ \\
\hline Services provided by forests & $\begin{array}{l}\text { - } \text { Carbon sequestration capacity } \\
\text { - } \\
\text { - Refhnobotany } \\
\text { managed forests) } \\
\text { - Visitor Experience-visitor infrastructure (for example, trails), recreation } \\
\text { (for example, hunting, fishing, hiking), visual quality } \\
\text { - Water quality and quantity (temperature regime, summer low flows, } \\
\text { sediment transport, salmonid requirements) } \\
\text { - Subsistence } \\
\text { Nutrients and material exchange with marine system (marine-derived } \\
\text { nutrients, sediments, wood, and others) }\end{array}$ \\
\hline
\end{tabular}

Table 2.2. Management tools available to respond to climate change effects.

[Not all tools are available to all agencies]

\begin{tabular}{|c|c|}
\hline Type of tool & Specific action \\
\hline $\begin{array}{l}\text { Active (manipulative) } \\
\text { management }\end{array}$ & $\begin{array}{ll}\text { - } & \text { Harvest plan (cut levels, length of rotation, species harvested and planted, stand } \\
& \text { density control) } \\
\text { - } & \text { Fertilization } \\
\text { - } & \text { Chemical control of competing vegetation } \\
\text { - } & \text { Invasive and pest management/treatments } \\
\text { - } & \text { Transportation infrastructure design and maintenance } \\
\text { - } & \text { Increase diversity of planted species (including genetic diversity) } \\
\text { - } & \text { Restoration activities } \\
\text { - } & \text { Flow regulation (for example, dam removal, irrigation and municipal and } \\
\text { - } & \text { industrial[(M\&I] withdrawals) } \\
\text { - } & \text { Set hanagement - prescribed burns, fire suppression } \\
\text { - } & \text { Augmentation (for example, reintroduction, assisted migration, captive breeding) } \\
\text { - } & \text { Hazard management }\end{array}$ \\
\hline $\begin{array}{l}\text { Other management } \\
\text { activities conducted } \\
\text { within agencies }\end{array}$ & $\begin{array}{l}\text { - Land/water acquisition or easements } \\
\text { - Management planning to consider climate change effects } \\
\text { - } \text { Menitoring for adaptive management } \\
\text { - Land use/allowable use regulations } \\
\text { - Involvement of Tribes and First Nations in land management decisions } \\
\text { - } \text { (consultations) } \\
\text { Emergency response preparedness }\end{array}$ \\
\hline $\begin{array}{l}\text { Influence decisions and } \\
\text { actions of others }\end{array}$ & $\begin{array}{l}\text { - Support ability of timber industry to harvest, transport, and mill smaller trees } \\
\text { - } \\
\text { - } \text { Advovision of interpretative and educational materials } \\
\text { - Formal memorandums of understanding between Tribes and First Nations with } \\
\text { management entities }\end{array}$ \\
\hline
\end{tabular}


Table 2.3. Information required by resource managers to use management tools to meet management goals for timber resources.

[Numbers in parentheses following information needs indicates what is currently known: 1, nothing; 2, a little; 3, a lot; 4, enough]

\begin{tabular}{|c|c|c|}
\hline Management goals-Timber & Tools & Information Needs \\
\hline $\begin{array}{l}\text { - Maximize timber production } \\
\text { presently and in future } \\
\text { - While maximizing production of: } \\
\text { O Other resources with market } \\
\text { value } \\
\text { Resources with non-market } \\
\text { value } \\
\text { Tribal and First Nations } \\
\text { resources } \\
\text { O Other forest services } \\
\text { - And maintaining desired } \\
\text { characteristics of forested } \\
\text { ecosystems }\end{array}$ & $\begin{array}{l}\text { - Harvest plan } \\
\text { - Cut levels, rotation length, } \\
\text { species harvested and planted } \\
\text { - Management during growth } \\
\text { - Fertilization, stand density } \\
\text { control, chemical control of } \\
\text { competing vegetation } \\
\text { - Infrastructure development } \\
\text { and maintenance } \\
\text { - Public outreach }\end{array}$ & $\begin{array}{l}\text { - Range shifts of timber species (2) } \\
\text { - Site-specific growth rates in the } \\
\text { future climate (3) } \\
\text { - Genetic variability within species } \\
\text { (2) } \\
\text { - Predict specific climate factors } \\
\text { relevant to particular species (3) } \\
\text { - Effects of microclimate factors (3) } \\
\text { - Economic factors } \\
\text { O Global supply and demand, } \\
\text { including niche products (2) } \\
\text { Best use/return from } \\
\text { harvested products, especially } \\
\text { smaller trees (2) }\end{array}$ \\
\hline
\end{tabular}

Table 2.4. Information required by resource managers to use management tools to meet management goals for wildlife and fish resources.

[Numbers in parentheses following information needs indicates what is currently known: 1, nothing; 2, a little; 3, a lot; 4, enough; not all information needs were scored for current knowledge]

\begin{tabular}{|c|c|c|}
\hline $\begin{array}{c}\text { Management goals-Wildlife and } \\
\text { fish }\end{array}$ & Tools & Information needs \\
\hline $\begin{array}{l}\text { - Maintain harvestable } \\
\text { populations of subsistence, } \\
\text { commercial, and } \\
\text { recreational/sporting wildlife } \\
\text { and fish } \\
\text { - Minimize any negative } \\
\text { effects on other desired } \\
\text { resources and services }\end{array}$ & $\begin{array}{l}\text { - Harvest of wildlife and fish } \\
\text { (subsistence, } \\
\text { recreation/sporting) } \\
\text { - All decisions affecting } \\
\text { timber and habitat } \\
\text { - Forest management to meet } \\
\text { needs of specific species } \\
\text { - Control of competitive/ } \\
\text { predatory species } \\
\text { - Population augmentation } \\
\text { - Public education to } \\
\text { minimize adverse effects }\end{array}$ & $\begin{array}{l}\text { - Inventory of current species abundance, } \\
\text { health, and diversity, especially } \\
\text { threatened species (2) } \\
\text { - Vulnerability of species to anticipated } \\
\text { climate changes (2) } \\
\text { - Future location of habitats (1) } \\
\text { - Regeneration needs of at-risk species } \\
\text { - Changes to food webs from climate } \\
\text { change } \\
\text { - Climate change effect on vital rates of } \\
\text { harvestable species } \\
\text { - Identify adaptation and mitigation } \\
\text { actions } \\
\text { - Predict pest responses and effects } \\
\text { - Predict predator and competitive } \\
\text { species responses } \\
\text { - Consider unanticipated consequences of } \\
\text { augmentation } \\
\text { - Consider effects on current "keystone" } \\
\text { species and results for ecosystems }\end{array}$ \\
\hline
\end{tabular}


Table 2.5. Information needs required by resource managers to use management tools to meet management goals for habitat.

[Numbers in parentheses following information needs indicates what is currently known: 1, nothing; 2, a little; 3, a lot; 4, enough]

\begin{tabular}{|c|c|c|}
\hline Management goals-Habitats & Tools & Information needs \\
\hline $\begin{array}{l}\text { - Maintain sufficient quantity and } \\
\text { quality of habitats to support viable } \\
\text { populations of high-priority species } \\
\text { - Maintain biodiversity } \\
\text { - Minimize any negative effects on: } \\
\text { O Production of other resources } \\
\text { with non-market value } \\
\circ \quad \text { Resources with economic } \\
\text { value } \\
\circ \quad \text { Tribal and First Nations } \\
\text { resources } \\
\circ \quad \text { Services provided by forests }\end{array}$ & $\begin{array}{l}\text { - Land/water } \\
\text { - } \text { acquisition/easements } \\
\text { - } \text { Enhanage for resilience } \\
\text { - Restoration-Identify priority } \\
\text { areas } \\
\text { - Invasive species management } \\
\text { - Flow regulation } \\
\text { - Plant diverse species; produce } \\
\text { native plant material } \\
\text { - Reduce other stressors } \\
\text { ○ Modify allowable uses } \\
\text { O Modify infrastructure }\end{array}$ & $\begin{array}{l}\text { - Identify habitats at risk (3) } \\
\text { - Vulnerability assessment of at- } \\
\text { risk habitats (2) } \\
\text { - Forecast new locations of habitats } \\
\text { and what will replace them (1) } \\
\text { - Identify adaptation and mitigation } \\
\text { tools to maintain existing habitats } \\
\text { (3) } \\
\text { - Predict pest responses (2-) } \\
\text { - Predict degrading and } \\
\text { competitive vegetation responses } \\
\text { (1) } \\
\text { - Predict adverse effects of } \\
\text { restoration (1) } \\
\text { - Identify supportive natural } \\
\text { disturbance regimes and how } \\
\text { climate will affect them (3,2) }\end{array}$ \\
\hline
\end{tabular}

Table 2.6. Information required by resource managers to use management tools to meet management goals for water quality and quantity.

[Numbers in parentheses following information needs indicates what is currently known: 1, nothing; 2, a little; 3, a lot; 4, enough]

\begin{tabular}{|c|c|c|}
\hline $\begin{array}{l}\text { Management goals-Water quality and } \\
\text { quantity }\end{array}$ & Tools & Information needs \\
\hline $\begin{array}{l}\text { - Maintain water temperatures, } \\
\text { summer low flows, and sediment } \\
\text { levels to meet salmon requirements } \\
\text { - Prevent introduction of pollutants } \\
\text { - Minimize any negative effects to } \\
\text { other desired resources and services }\end{array}$ & $\begin{array}{l}\text { - Flow regulation } \\
\text { - Infrastructure design, placement, } \\
\text { maintenance, use } \\
\text { ○ Road crossing, stream- } \\
\text { adjacent roads, road- } \\
\text { associated slope failures } \\
\text { - Harvest plan, restrictions } \\
\text { - Fire use/suppression/ retardants } \\
\text { - Other chemical use } \\
\text { - Land use restrictions on recharge } \\
\text { areas }\end{array}$ & $\begin{array}{l}\text { - How do forests, riparian shading and } \\
\text { large wood affect water quality } \\
\text { (especially temperature)? (4) } \\
\text { - Effects of forest management on } \\
\text { sedimentation and water quality of } \\
\text { in-stream habitats (4) } \\
\text { - Predict future demand for water and } \\
\text { energy }(2,3)\end{array}$ \\
\hline
\end{tabular}


Table 2.7. Information needs required by resource managers to use management tools to meet management goals for cultural sites and resources.

[Numbers in parentheses following information needs indicates what is currently known: 1, nothing; 2, a little; 3, a lot; 4, enough; not all information needs were scored for current knowledge]

\begin{tabular}{|c|c|c|}
\hline $\begin{array}{l}\text { Management goals-Cultural } \\
\text { sites and resources }\end{array}$ & Tools & Information needs \\
\hline $\begin{array}{l}\text { - Prevent damage to or loss } \\
\text { of cultural sites and } \\
\text { resources } \\
\text { - Enable access and } \\
\text { appropriate conditions for } \\
\text { use (for example, privacy) }\end{array}$ & $\begin{array}{l}\text { - Laws } \\
\text { - Memorandums of understanding } \\
\text { between Tribes or First Nations and } \\
\text { management entities } \\
\text { - Information sharing about location } \\
\text { and importance of sites } \\
\text { - Infrastructure } \\
\text { - Involvement of Tribes and First } \\
\text { Nations in land-management decisions } \\
\text { O Pre-harvest reviews, forest } \\
\text { practices, management planning, } \\
\text { and fire use and suppression }\end{array}$ & $\begin{array}{l}\text { - Location and importance of sites } \\
\text { (can be proprietary) } \\
\text { - What other stressors may be } \\
\text { affecting cultural sites and how do } \\
\text { they interact with climate? (3, } \\
\text { resource dependent) } \\
\text { o Energy development } \\
\text { opportunities } \\
\text { - Site-specific assessment of climate } \\
\text { change effects }(2)\end{array}$ \\
\hline
\end{tabular}

Table 2.8. Information required by resource managers to use management tools to meet management goals for visitor experience.

[Numbers in parentheses following information needs indicates what is currently known: 1, nothing; 2, a little; 3, a lot; 4, enough; not all information needs were scored for current knowledge]

\begin{tabular}{|c|c|c|}
\hline $\begin{array}{l}\text { Management goals-Visitor } \\
\text { experience }\end{array}$ & Tools & Information needs \\
\hline $\begin{array}{l}\text { - Maximize visitor access to } \\
\text { public forests } \\
\text { - Maintain visitor safety } \\
\text { - Protect forest resources } \\
\text { from visitor impacts }\end{array}$ & $\begin{array}{l}\text { - Infrastructure } \\
\text { - Forest management } \\
\text { - Management of access, uses, } \\
\text { conflicting uses } \\
\text { - All decisions affecting biodiversity } \\
\text { and habitat quality (see tables } 2.5 \text { and } \\
\text { 2.9) } \\
\text { - Provision of interpretive and } \\
\text { educational materials } \\
\text { - Emergency response preparedness } \\
\text { - Hazard management }\end{array}$ & $\begin{array}{l}\text { - How will access to public lands and } \\
\text { visitor infrastructure be limited or } \\
\text { made harder by climate change, } \\
\text { flooding, and road damage? (3) } \\
\text { o How much harder and what are cost- } \\
\text { effective ways to maintain access? } \\
\text { - Anticipate changes in flora and fauna } \\
\text { (2) } \\
\text { - Understand perceptions of visitors and } \\
\text { how to inform their expectations (2) }\end{array}$ \\
\hline
\end{tabular}


Table 2.9. Information required by resource managers to use management tools to meet management goals for biodiversity.

\begin{tabular}{|c|l|l|}
\hline $\begin{array}{c}\text { Management Goals- } \\
\text { Biodiversity }\end{array}$ & \multicolumn{1}{c|}{ Tools } & \multicolumn{1}{c|}{ Information Needs } \\
\hline - Maximize biodiversity & $\begin{array}{l}\text { - Forest thinning to increase understory diversity } \\
\text { - Restore to expand habitat continuity and/or } \\
\text { connectivity } \\
\text { - Invasive species management } \\
\text { - Wildlife tree patches } \\
\text { - Protect biodiverse areas } \\
\text { - Designation \& conservation of keystone spp. } \\
\text { - Protect ecological function of supporting habitats } \\
\text { - Fire use } \\
\text { - Harvest to mimic distr. reg. } \\
\text { - Pest and disease control } \\
\text { - Species selection } \\
\text { - Gene conservation }\end{array}$ & $\begin{array}{l}\text { See "Wildlife and Fish", } \\
\text { and "Habitat" sections }\end{array}$ \\
\end{tabular}

Table 2.10. Information required by resource managers to use management tools to meet management goals for achieving fire adaptation and resilience.

\begin{tabular}{|c|l|l|}
\hline $\begin{array}{c}\text { Management goals -Fire } \\
\text { adaptation/resilience }\end{array}$ & \multicolumn{1}{c|}{ Tools } & \multicolumn{1}{c|}{ Information needs } \\
\hline $\begin{array}{l}\text { - Create fire-resilient and fire- } \\
\text { adapted forests }\end{array}$ & $\begin{array}{l}\text { - Fuel treatments (in limited areas) } \\
\text { - Species and stocking control } \\
\text { - Fires for resource benefit (for example, let-burn } \\
\text { policies) } \\
\text { Tax structure }\end{array}$ & $\begin{array}{l}\text { Participants had } \\
\text { insufficient time to } \\
\text { identify information needs }\end{array}$ \\
\hline
\end{tabular}




\section{Chapter 3. Forage Fish Workshop}

\section{Introduction}

The workshop to identify the information needs of forage fish managers was held in Seattle, Washington, on January 31, 2013. Nineteen people attended, representing Federal, State, Tribal, and private entities, with some individuals representing more than one entity (see appendix 3 for a list of participants and affiliations):

Alaska Department of Fish and Game

Cowlitz Tribe

Hoh Tribe

National Park Service, Olympic National Park

National Oceanic and Atmospheric Administration Fisheries

Northwest Power and Conservation Council

Office of the Washington State Climatologist

Oregon Department of Fish and Wildlife

Pew Environmental Group

Port Gamble S'Klallam Tribe

Puget Sound Partnership

Quileute Tribe

Suquamish Tribe

Washington State Department of Fish and Wildlife

University of Washington

North Pacific Landscape Conservation Cooperative

U.S. Geological Survey

The workshop was organized by Theresa Liedtke and facilitated by Karen Jenni (Insight Decisions) using the principles of decision analysis (Keefer and others, 2004) described in chapter 1, and had the same goals as the forest resources workshop: Determining valued resources, defining potential climate change effects, and outlining decisions managers may take in response to climate change and consequent information needs. The workshop agenda is shown in appendix 4.

\section{Background}

Forage fish occupy a central position in marine food webs, linking the energy produced by plankton to larger fishes, birds, and marine mammals. The title of "forage fish" or "bait fish" is applied to wide variety of species throughout the world, but they share some common characteristics. They are small fish that show rapid growth, tight schooling behavior, and large changes in abundance or distribution in response to environmental drivers (Baumgartner and others, 1992; Curry and others, 2000). Some easily recognized examples of forage fish include herrings (Clupea species), sardines (Sardinops and Sardinella species), and anchovies (Engraulis and Anchoa species). They are targeted for harvest by some of the largest fisheries in the world, and demand for products derived from forage fish is increasing (Smith and others, 2011). Direct harvest, combined with their natural sensitivity to environmental influences, makes them vulnerable to population crashes that could result in fundamentally changed ecosystem function. Although the value of commercial harvest of these species has long been recognized, their value in an ecosystem management setting has only more recently been 
appreciated. The challenge facing forage fish managers today is to determine a level of harvest that leaves enough forage fish available to retain full ecosystem function. Factoring in the anticipated effects of climate change makes this balance even more complex, and strengthens the need to manage forage fish collaboratively across large spatial extents.

Because forage fish generally are pelagic, many of the issues related to forage fish are outside the scope of the NPLCC, which is limited to the nearshore. However, there are a wide variety of life history patterns within the group, including life history patterns that bring populations to nearshore locales and are directly relevant to the S-TEK priority topics identified by the NPLCC. Several species of forage fish have close connections with nearshore habitats for spawning and rearing. For example, Pacific herring deposit eggs on submerged aquatic vegetation in the nearshore, such as kelp and eelgrass, and surf smelt and sand lance deposit eggs on the upper intertidal area on mixed sand and gravel beaches. The shoreline association of these forage fish species makes them vulnerable to human perturbations, such as contaminant exposure and shoreline development, as well as climate change effects, such as sea-level rise. Another life history that deserves special consideration is the group of species that are anadromous, meaning they spend most of their lives in the ocean, but migrate to freshwater to spawn. Examples include river herring (Culpeoides papuensis), longfin smelt (Spirinchus thaleichthys), and eulachon (Culpeoides papuensis). This life history puts these species in double jeopardy, as they are vulnerable to human and climate change effects in both marine and freshwater systems. For the workshop participants and the purposes of this document, eulachon were the primary anadromous fish species discussed.

\section{Setting the Stage}

Forage fish link with most of the priority topics presented in the S-TEK Strategy (Jenni and others, 2012; see chapter 1). Hydrological regime shifts will affect rivers and streams, and may, therefore, influence anadromous forage fish as they enter freshwater to spawn (topics 1 and 4), as well as the forage fish that rely on the nearshore owing to changes in the quantity, quality, and timing of sediments delivered to nearshore areas (topic 1). Changes in streamflow also may influence the risk of contaminant delivery to the nearshore where vulnerable eggs are deposited on beaches (topic 1). Sealevel rise and storm events will affect shorelines where forage fish deposit eggs and require habitat for rearing (topic 3). Spawning habitats will be squeezed between rising sea levels and increased shoreline armoring (building physical structures such as concrete walls or rock piles to prevent beach erosion) that landowners likely will install to protect property. Invasive species such as American shad (Alosa sapidissima) and Spartina may affect forage fish by direct competition or through disease vector processes (topic 5). In addition to linkages with NPLCC priority topics (Jenni and others, 2012), forage fish conservation fits well with the guiding principles of the NPLCC because they are important to First Nations, are widely distributed and managed across the coastal landscape, and will benefit from coordination, collaboration, and capacity-building for decision-makers.

Forage fish have recently been the focus of attention in both political and scientific settings (Pikitch and others, 2012). As such, there have been several workshops and symposia related to forage fish management and protection. One such gathering was a research symposium titled "Conservation and Ecology of Marine Forage Fishes", hosted by the Northwest Straits Commission, the U.S. Geological Survey, Washington Department of Fish and Wildlife, and The Puget Sound Partnership at the University of Washington, Friday Harbor Laboratories in September 2012. In an effort to provide workshop participants a summary of this locally relevant symposium, a poster was presented which summarized a list of priority science and policy needs for forage fish in Washington and British Columbia which was published as part of the symposium proceedings (Liedtke and others, 2013). The 
list of priority needs provided an update to workshop participants that did not attend the symposium, and as a starting point for discussions. Although both the symposium and the workshop focused on forage fish, the goals and participants did not have significant overlap.

\section{Influence Diagram}

The influence diagram structure was used as a framework for identifying management goals and tools, valued resources, and potential effects of climate change on key ecosystem processes and components (fig. 3.1). For some topics, the group discussion was detailed enough to require the construction of submodels (for example, see fig. 3.2 for the submodel on life history parameters). Topics with submodels are shown in darker blue rounded rectangles in the influence diagram.

\section{Forage Fish Resources within the North Pacific Landscape Conservation Cooperative}

Identifying the valued forage fish resources within the NPLCC was challenging, as there is no universally agreed-upon definition of "forage fish." A traditional, narrowly focused definition includes small, silvery, pelagic fish that form tight schools and are eaten by larger predators. Herrings and anchovies fit this traditional definition and are readily recognized as forage fish. Other definitions consider "forage fish" as any prey item that supports higher trophic levels, and may include species other than fish. For example, squid (for example California market squid, Loligo opalescens) and krill (Euphausia pacifica) both fulfill the same ecological role and could be classified as "forage fish." Additionally, many fish species (including salmon; Oncorhynchus species) have larval and juvenile stages that could be considered "forage fish" during those parts of their life cycle. To focus the discussions for the workshop, the participants agreed to use the more traditional definition of forage fish, noting that this approach would target the fish that meet the definition throughout their life cycle, making it more relevant to the workshop topic. The participants defined 14 species of forage fish that reside, at least partially, within the NPLCC coverage area, and noted their general distribution (table $3.1)$.

\section{Management Goals Related to Valued Forage Fish Resources}

The overarching goal of forage fish managers is to maintain healthy forage fish populations, but within that larger goal there are several considerations that vary across agencies and jurisdictions. These considerations are represented by the submodel referred to as "Maintain healthy FF populations" on the right side of figure 3.1 and are shown in figure 3.3.

Details of the management goals related for forage fish identified during the workshop are shown in table 3.2. They include direct and indirect economic benefits that forage fish provide, as well as cultural values for Tribes and First Nations. The understanding that forage fish are critical to the function of a healthy ecosystem is growing, but workshop participants felt that not all agencies may have incorporated this knowledge into their management processes. For example, some agencies may set harvest limits based strictly on the amount of fish that can be removed from the population so that the population is maintained at a level where it can be harvested again in future years. Other agencies may have adopted the ecosystem management approach and set more conservative harvest limits, accounting not only for the current and future needs for direct harvest, but also allowing for anticipated loss for species that consume forage fish. The topics of ecosystem function, managing with common goals, and providing learning (table 3.2) stem from the group's discussion of these differences in management goals and the hope that, with increased knowledge and coordination, the differences can be brought into closer alignment. 


\section{Potential Climate Change Effects on Forage Fish}

Climate change will affect the Pacific Ocean along the West Coast, with implications for forage fish throughout the NPLCC coverage area. Using the influence diagram structure, the workshop group identified potential effects in three main categories - direct climate effects, ocean chemistry effects, and changes in freshwater quality based on the timing and intensity of runoff. These categories are represented by submodels within the influence diagram (fig. 3.1). The direct climate effects include the amount and seasonality of precipitation, air temperature, ocean surface temperature, the location and timing of upwelling, sea-level changes, and localized storm activity (fig. 3.4). These direct effects will influence changes in ocean water quality, including dissolved-oxygen concentrations, nutrient loads, turbidity, coarse suspended-sediment load, and ocean acidification. The timing and intensity of freshwater runoff will influence freshwater quality, including turbidity, suspended sediment, and the concentration of endocrine disrupting compounds and other contaminants. Changes in the ocean climate and chemistry also will influence primary productivity, with corresponding effects through the food chain, from forage fish to higher trophic levels.

Workshop participants were especially interested in climate change effects on forage fish habitat. The predicted changes in timing and intensity of precipitation may result in beach migration or loss, which could reduce the amount of spawning substrate available for surf smelt and sand lance. Eulachon spawning also would be affected because runoff events will likely reduce the availability of coarse sand and increase turbidity. The predicted rises in sea level will lead to new or enhanced shoreline armoring to protect property, further reducing spawning substrate for some species. Submerged aquatic vegetation, such as eelgrass and kelp, are important habitat for forage fish for spawning and rearing, and will be affected by multiple factors including sedimentation and turbidity from runoff events, rising sea level, shoreline armoring, and storm events.

Because forage fish play a central role in marine food webs, climate change likely will influence their populations through effects on lower trophic levels (their food source) and effects on higher trophic levels (their predators). Changes in ocean chemistry and upwelling timing and location will influence phytoplankton and zooplankton abundance, which may, in turn, alter the abundance or distribution of forage fish. Additionally, the predators of forage fish (birds, marine mammals, and larger fish) also will be influenced by climate change, so the effects on forage fish are difficult to predict. The distribution of marine species is predicted to change, with a general range shift to the north to mitigate for warmer water temperatures. Not all species, however, will make the shift (for example, those with greater thermal tolerance), so unique species assemblages may result.

Although forage fish occur throughout the NPLCC coverage area, workshop participants discussed the special consideration given to Alaska. Alaska has an abundance of forage fish habitat because of its long coastline and large availability of freshwater (glaciers, rivers, and streams). Climate change effects are predicted to be more intense and to occur more rapidly in Alaska compared with other regions, including increases in storm activity. The productive commercial fisheries in Alaska are already being affected by the decrease in sea ice in the Bering Sea (Grebmeier and others, 2006; Mueter and Litzow, 2008) and corresponding changes to species composition and timing of the plankton blooms critical for many marine species. These changes are expected to accelerate. 
The specific effects that climate change will have on individual species of forage fish are difficult to predict. Accurate prediction of specific future ocean conditions is challenged by normal climate variability and the lack of modeling at the regional scale. Prediction of fish responses to changing climate has additional challenges - there is uncertainty as to whether climate effects will be lethal to forage fish or will lead to range shifts to accommodate changes, or whether species will adapt to these effects.

\section{Potential Management Actions to Mitigate Climate Change Effects}

Managers have a suite of potential decisions they can make or actions they can take to mitigate climate change effects on forage fish. The workshop group organized these potential management actions into three broad categories (fig. 3.5): (1)Decisions about managing forage fish at the highest spatial scale (hereafter called landscape level), (2) decisions about activities that directly affect the landscape, and (3) decisions that may apply more broadly (other types of decisions). Under each of these categories was a general goal, shown in a white box in figure 3.5. For example, harvest management was the general goal for the group of decisions about managing forage fish at the landscape level. Details of the workshop group discussions on potential management actions are shown in tables 3.3-3.5, with each table focused on one of the broad categories from figure 3.5.

The workshop group extensively discussed the permitting processes currently (2013) in place and the need to coordinate these efforts for an improved ability to better evaluate the cumulative effects of multiple jurisdictions. Permitting authority for activities that may affect forage fish currently resides with States, counties, parks, coastal communities, and marine resource entities, and is variable across the region. For example, the entities that grant permits for work at private as compared to public beaches vary across States. The roles and responsibilities of these various agencies are unclear to fishery managers in attendance, resulting in fishery managers having limited ability to influence permitting outcomes. The workshop group was concerned that, with so many agencies operating in separate jurisdictions and with individual legal mandates, the cumulative effects of climate change on forage fishes would not be evaluated or even considered. There is a clear need for collaboration and coordination on these permitting processes, as well as for an improved integration of fisheries managers and species-specific information into the process.

Outreach and education are management tools that can be used to support various management goals. The growing understanding of the value of forage fish in marine ecosystems could be bolstered with additional outreach activities. Because these fish are small and inconspicuous, they do not command the same level of attention as larger, more charismatic species, but they are critically important in supporting the species that draw public attention. Outreach and education are powerful tools to help the public make this connection, and then to promote low-impact shoreline building practices and controlling point sources of pollutants and contaminants through freshwater and stormwater inputs into the nearshore. Outreach also will be beneficial to establish and support citizen science efforts related to forage fish. Several groups of "beach watchers" (organized by Washington State University County Extension Directors, http://www.Beachwatchers.wsu.edu) participate in surveys for forage fish spawning activity on beaches in Puget Sound, and this effort could be expanded to other geographic areas or topical areas (environmental conditions or vegetation monitoring) to meet some information needs. 


\section{Information Needs}

The workshop group discussed the current (2013) state of knowledge of forage fish, and identified information gaps that might affect the ability to choose and enact management actions. Five main themes of the discussion were developed into four categories information needed to support (1) harvest decisions, (2) permitting decisions, (3) decisions about habitat protection, and (4) decisions about management of other species to protect forage fish. Although the information needs are presented separately for each category, there are obvious connections between them. For example, the management goals for the categories are similar so that meeting the needs for one category likely will support the goals of other categories. For each of the four categories, the discussions generated some tools or decisions specific to that category as well as information needs that might limit the use of those tools. The four categories are summarized in sections, "Harvest Decisions," "Permitting Decisions," "Habitat Requirements and Availability," and "Management of Other Species," respectively. Throughout the discussions there were several high-level questions and needs that apply generally to all four categories. These questions include:

- What is the appropriate threshold for the quality and quantity of information "needed" to make a confident decision about forage fish management? There are large information gaps about basic life history parameters for most species of forage fish, and yet managers currently are compelled to make decisions about harvest, permitting, and protection of these species without this information, and without a full understanding of the potential effects of their decisions. How much information is enough to make a defensible (legally defensible if necessary) decision?

- What is the value of forage fish that are not directly harvested but are left in the ecosystem to contribute to the food web? Can or should this value be viewed in economic or monetary terms? What are the appropriate trade-offs between direct harvest (with a known commercial value) and harvest limitation for ecosystem management (with an identifiable commercial "loss" in exchange for an ecosystem benefit)?

- How can managers effectively evaluate the cumulative effects of multiple stressors to forage fish? These species are affected by human activities on the shoreline that reduce or damage habitat, direct harvest, predation by a whole suite of predators, and mortality associated with human effects (contaminants, disease, bycatch, etc.). Climate change will have additional effects. Estimating the cumulative effect would allow more effective management of each of the risks to these species.

\section{Harvest Decisions}

Direct harvest of forage fish resources is where most management actions currently occur. All management entities allow harvest; some embrace ecosystem management and set conservative harvest limits to support the needs of predators. Individual agencies use the best available information to assess current populations and to forecast the effect of a given level of harvest for a given stock. The goals in harvest management are to maintain productive fisheries, including stock and age class diversity, and to avoid Endangered Species Act listing of commercial stocks so that harvest can continue (table 3.6). Healthy populations of forage fish support other goals, including indirect economic benefits and First Nations cultural values. The tools that managers can use include innovative approaches, such as including ecologists (and not just statisticians), into harvest determinations, conducting species relocations in areas where abundance is low, using artificial propagation for critical stocks, and establishing refuges to support current and future generations of forage fish (table3.6). Information needs to support harvest decisions primarily were related to predicting the abundance of the fish, 
specifically at the stock level for each age class, and to quantifying the needs of predators, under current and future conditions. Considering that managers are currently struggling to get appropriate and accurate abundance information on forage fish species in order to make harvest decisions, the influence of coming changes in ocean chemistry will only complicate an already challenging problem. Workshop participants also highlighted the need to make this information known and accessible to all the relevant management entities.

\section{Permitting Decisions}

The permitting processes currently in place throughout the NPLCC are diverse and are managed by multiple agencies, even within the same State. In the workshop group discussions on permitting, the focus was primarily on shoreline development permits for construction or modifications of seawalls, armoring, and overwater structures, such as docks, which affect those forage fish dependent on the nearshore environment (for example, herring, surf smelt, and sand lance). In a broad sense, the discussion on permitting also included dredging and general construction work in and around the water that might affect eulachon or eulachon habitat as they migrate into freshwater. The fundamental goals that permitting processes are intended to support were similar to those outlined for harvest (and the other categories), with an additional goal of getting the diverse group of permitting agencies to work together (table 3.7). The workshop group was concerned that each individual agency was working in an isolated setting, making decisions about whether or not to grant permits for small changes to the shoreline, but that there was no agency responsible for assessing the cumulative changes that might be authorized in a local area or the effects of that overall change on forage fish resources. Moreover, continued population growth, the threat of sea-level rise, and the demand for new energy sources (such as tidal energy) will make managing permitting decisions more challenging in the future than they are today.

The list of permitting-related tools available includes enforcing existing regulations, requiring data collection prior to permit approval, marine spatial planning, and preservation and restoration of shoreline areas (table 3.7). The information needs to help manage permitting decisions are based on two main themes - forage fish basic life history information and habitat requirements (table 3.7). More accurate and reliable information about the spawn timing and hatch timing for each forage fish species will enable managers to define periods when proposed activities on the shoreline can be safely conducted. The current spawning locations for forage fish populations and the forecast future locations are critical for permitting decisions, and are a significant need in some areas (such as the outer coast of Washington). Finally, an understanding of the specific habitat requirements for forage fish species is lacking. For example, herring deposit eggs on submerged aquatic vegetation, but eggs also have been found on pilings and other man-made structures. Does the substrate make a difference to the health of the population? Similarly, shaded areas over a beach where surf smelt spawn in the summer are beneficial, but is the survival of the eggs on beaches without shade affected? Any information collected on the basic life history or habitat requirements of forage fish species will inform permitting decisions.

\section{Habitat Requirements and Availability}

Although habitat requirements and availability are presented as a separate category for information needs, this topic clearly supports, and is supported by, other categories. The need to better understand habitat for forage fish has been highlighted in other recent gatherings of forage fish researchers and managers (Liedtke and others, 2013) as a high-priority need. Management goals for this category were similar to goals for the other categories, with several additional goals. These include providing learning to support ecosystem management, managing freshwater flow and stormwater flow 
to benefit forage fish, managing forestland to control sediment, and mitigating dredging activity and disposal (table 3.8). Several of the tools that could be used to manage habitat also were listed for other categories, such as establishing refuges, enforcing existing regulations, reviewing historical data, and conducting field studies to collect data on distribution and phenology. Additionally, there were several novel tools listed for habitat, including evaluating site fidelity with historical data and TEK, using citizen science monitoring efforts, and fostering collaborative sample collection and processing so that individual fish could be used for multiple assays such as genetics, contaminants, and age (table 3.8).

Many of the information needs for habitat match the needs defined for other categories - for example, distribution and timing information, basic life stage parameters, and shoreline habitat requirements (table 3.8). Other needs were unique to this category-LiDAR surveys and habitat models to identify critical habitat characteristics, sea-level rise predictions at the local level and their effect on beach habitats, vegetation monitoring, catch data from commercial fisheries, and information on site fidelity for species using shoreline habitat. Site fidelity is an important consideration for habitat use so managers can assess the long-term likelihood that a particular area will be used by forage fish and whether damage at one site can be mitigated by appropriate habitat at an alternate site. An information need related to forage fish habitats in freshwater is a better understanding of fish passage barriers, such as dams that may block access to spawning habitat.

\section{Management of Other Species}

Because forage fish play a central role in marine food webs, management of this resource has close linkages with the management of larger, more iconic species, such as salmon, sea birds, and marine mammals. The management goals identified for this category include maintaining productive fisheries and ecosystem function, minimizing non-native species, minimizing constraints on other activities, and maximizing indirect economic benefits, such as ecotourism (table 3.9). The management tools and information needs discussed for this category include efforts to control non-native species, such as Spartina and American shad, as well as efforts to support populations of forage fish and the predators that rely on them.

Spartina (Spartina spp.) is an invasive grass found in intertidal wetlands, and currently is targeted for eradication in several areas within the NPLCC coverage area (for example, Willapa Bay and Humboldt Bay). The challenge is that Spartina is effective at converting mud flats into marshes, and at reducing rearing habitat for clams, oysters, juvenile salmon, and potentially other species. Chemical treatments are used as a control measure. Because information is lacking on the rearing habitats required for many forage fish species, it is unclear how Spartina eradication efforts will affect forage fish.

American shad (Alosa sapidissima) are anadromous fish introduced to the West Coast more than 140 years ago. They are now abundant in the Columbia River and have significant overlap with the range of eulachon. There is concern that shad may contribute to population declines in eulachon because of direct competition or through a disease process. Adult shad are known to be vectors of diseases such as Ichthyophonus (Hershberger and others, 2010) that affect salmon and also may affect eulachon, but more information is needed to understand the potential risk.

Forage fish can be captured as bycatch during commercial fishing activities for other species. For example, the Washington shrimp trawl fishery catches eulachon, and efforts are underway to evaluate fishing practices and gear to reduce bycatch (Hannah and others, 2011). The issue of bycatch raised questions among the participants about what other forage fish might be at risk (table 3.9). A survey of commercial fishing logs would inform managers of other situations where bycatch modification might be considered. 
A wide variety of predators rely on forage fish as a primary part of their diet, including larger fish, such as salmon, seabirds, and marine mammals. These predators can influence the abundance and distribution of forage fish, which may affect other predators. The workshop participants highlighted several information needs related to the interactions between predators and forage fish (table 3.9). One of the main needs discussed was a better understanding of the diet of these predators and their true reliance on forage fish. Predators may switch prey items when prey availability is low or when the density of prey is patchy. To fully understand the needs of the predators, more information is needed about the amount of prey switching that occurs. A related information need is the consequences of phenology of forage fish availability on predators, and specifically on nesting birds that rely on forage fish being available when they are feeding their young. In terms of future conditions, information is needed about climate-induced changes to predator abundance, distribution, and phenology so that effects on forage fish populations can be predicted more accurately. Finally, participants discussed a management tool and related information need about predator "hot spots." If predator distributions were mapped, would they highlight areas where a variety of predators congregate to feed on high densities of forage fish? If so, could managers use these "hot spots" as special regulatory or management areas to support forage fish and predator populations? The need for a better knowledge of forage fish predators and their effects on forage fish management and harvest decisions was a common theme discussed throughout the workshop, and seems to be a priority information need.

\section{Approaches for Meeting Information Needs}

\section{Life Stage Parameters}

Forage fish are not yet fully recognized for the critical role they play in the trophic dynamics of marine systems. Although the level of awareness is growing, the lack of historical focus on many of these species has resulted in the current limited state of knowledge of the basic life stage parameters for these fish. This broad data gap has been highlighted consistently by forage fish researchers and managers (for example, Liedtke and others, 2013), and was a major theme in this workshop as wellbetter understanding of various life stage parameters was listed as an information need that would help support all of the various decision types listed here. The specific focus was on the need to improve understanding of the basic life stage parameters of forage fish both under current and future conditions, as the changing climate and ocean chemistry likely will have significant effects.

Many forage fish stocks have long been targeted by commercial and recreational fisheries, so managers at least have basic information about their abundance and distribution. However, information about forage fish is often lacking when they are present in areas where they are not regularly monitored to guide harvest, or for life stages that are not harvested. We lack information on the distribution, habitat requirements, and mortality risks for the egg stage and juvenile stages of most forage fish species, making it difficult for managers to know how to target habitat protection, for example. These data gaps are even larger for species that are not commercially harvested. With the growing momentum to manage forage fish stock using an ecosystem management approach, managers need to understand the role of forage fish (and other forage species) as a combined trophic level, not as individual species of commercial value. Predators may switch prey species when the availability of prey changes, making all forage fish equally critical to the balance of the ecosystem. 
Workshop participants identified various activities that could improve understanding of the basic life stage parameters of forage fish, including:

- Field studies of natural history (where are they and when) by species and life stage

- Acoustic trawl surveys

○ Beach seine surveys

- Tagging studies (acoustic telemetry)

- Mortality and fecundity

- Scale samples

- Laboratory/challenge studies

O Ocean acidification effects on physiology

- Disease resistance

- Predation studies

- Availability /relevance of TEK to predict changes

- Exploratory analyses using historical information

- Encouragement of environmental monitoring with industry

The tools were largely related to conducting studies or analyses of existing data. Field studies to help determine where fish are located and when they are present would be valuable. Examples include using acoustic trawl surveys, beach seine surveys, and tagging studies where, for example, acoustic telemetry is used to monitor fish movements. Field or laboratory studies also would be useful to evaluate mortality and fecundity, disease risk, and effects of ocean acidification on the physiology of various life stages. An assessment of whether TEK would be available and relevant for understanding current conditions or predicting future changes also was discussed. Finally, exploratory analyses using historical information (potentially including TEK) were proposed as a tool that could be used to better inform managers about life stage parameters. Related to this tool was a need to gather all historical information in a single location for improved accessibility.

Many of the information needs defined for this topic were related to improved modeling of forage fish abundance for population projections and harvest considerations. For example, more information is needed on the response of forage fish to stressors, such as disease and contaminants, especially under projected future ocean chemistry. The identification of larval stages is challenging and limits the ability to predict effectively the abundance of future age classes, and, therefore, limits reliable forecasting. Modeling efforts require an estimated mortality rate, and detailed information is lacking for most species. For example, how does the mortality rate vary with the age of the fish? How does the risk of predation change when the abundance of predators changes? How much prey-switching occurs for each predator and how does that influence the risk of predation? Under the broad theme of improved information about the risk of mortality, workshop participants showed much interest in better understanding the vulnerability of the egg stage of each species to current and future conditions (table 3.8). The participants considered the egg stage as the life stage most sensitive to human effects, such as contamination, ocean acidification, and changes on the shoreline (armoring, reduced shade cover, and reduced aquatic vegetation), and a priority information need. 
In summary, to be most useful to managers, information on the life stage parameters of forage fish should be for all species (not just the commercially harvested species), for all life stages, at appropriate spatial scales, and should include current and future forecast conditions.

\section{Habitat Management Handbook}

The workshop group discussed the value of a "quick guide" for agencies permitting at a local level as a unique way to unify permitting decisions based on basic life history and habitat information. The guide would highlight the specific local needs that should be included in a permitting decision. For example, a guide for Puget Sound might highlight the need for an assessment of the nearest source of sediment (to maintain the appropriate grain sizes on a spawning beach), the need for a map of summer spawning areas (to consider the need for shade on a spawning beach), and the need for a review of any armoring structures on adjacent properties because these are concerns in Puget Sound (but are not significant issues along the outer coast). These guides also could include forecasts of local changes anticipated under climate change, such as areas where spawning beaches would be lost or reduced because of sea-level rise. When used as a checklist, the workshop participants felt that such a tool would be very useful for permitting agencies.

\section{On-Going Activities}

The workshop group identified ongoing activities that could be leveraged or extended to meet some of the needs. Several proposals were generated, including:

- Evaluate the availability of archived samples from State, Federal, and Tribal groups doing spawning surveys of forage fish in Puget Sound to conduct diet studies, genetic analysis, and contaminants profiles.

- Extend the duration of a Washington State spawning beach survey on the outer coast to cover a full year and help define temporal habitat requirements.

- Provide funding to continue acoustic trawl surveys for Pacific herring in Puget Sound that formerly were conducted by the Washington State Department of Fish and Wildlife but have been discontinued.

- Expand the Tri-national sardine forum to include more forage fish species.

- Coordinate and collaborate with the seabird and marine mammal research and management communities to see if current or past studies might inform forage fish distributions.

- Monitor the Alaska Board of Fisheries and their upcoming review of how herring are managed and how research funding for the topic is handled to see if there are lessons that can be applied elsewhere. 


\section{Conclusions}

Forage fish resource management is challenging because the fish move readily across geographic and administrative boundaries, rely on different geographic areas for different life stages, and are subject to extreme abundance fluctuations, even under stable climate conditions. Managers are tasked with setting direct harvest limits that also will allow enough prey for important predator species and overall functioning of the ecosystem. Managers use statistical approaches and models that require input data about predicted abundance by age class, predation rate, and natural mortality that can be highly uncertain or even largely unknown. Climate change will add a layer of complexity to this already challenging setting as ocean chemistry changes and sea-level rise will affect a wide range of species and life stages. During the workshop, participants worked to define management actions that could be used to help manage forage fish under changing climate conditions and what information gaps might prevent managers from understanding the implications of different actions. The challenge is that current information focuses on the adult stages of forage fish species that are commercially targeted, but ecosystem function and population stability are founded on all life stages of all species. A consistent theme during the workshop was the need to improve the quality and quantity of life-stage and geographically specific information for the diverse set of forage fish resources within the NPLCC coverage area. It is a surprising reality that we have such a limited understanding of the basic biology of these fish.

The information needs under the categories of permitting decisions, life history parameters, and habitat requirements prompted the most discussion from the participants. These categories are closely linked, and meeting the information needs for one category will provide significant support to the other categories. The recent momentum on the topic of forage fish has resulted in several meetings and workshops for managers and researchers, and these general topics (permitting, basic biology, and habitat) consistently have emerged as priorities, even without specifically addressing climate change. Meeting these information needs and including accurate climate-change predictions at the locally relevant scale will allow managers to use the full suite of management tools to protect forage fish resources across large spatial scales. 


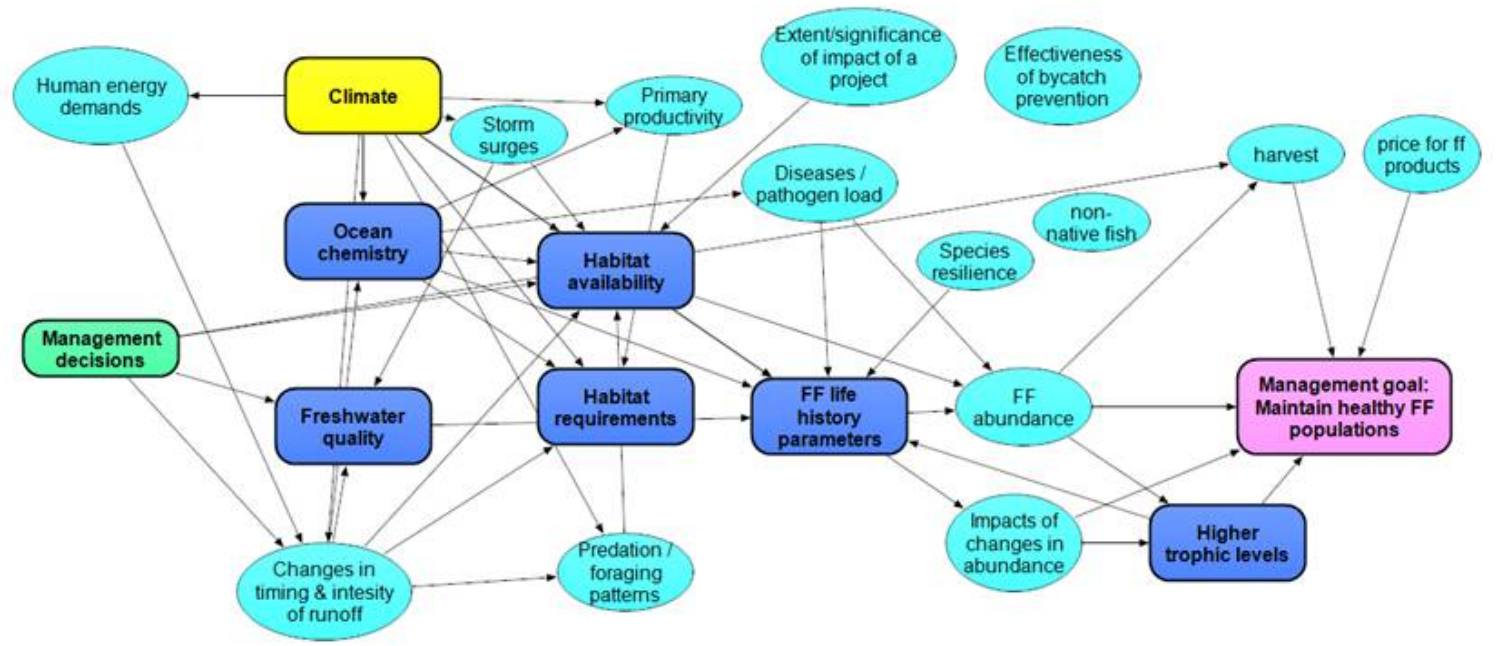

$F F=$ forage fish

Figure 3.1. Influence diagram showing management tools and effects of climate change on valued forage fish (FF) resources. Ovals indicate chance variables, and rounded rectangles indicate topics with submodels. The diagram summarized the workshop discussion and is not intended to be a comprehensive representation of all possible relationships. 


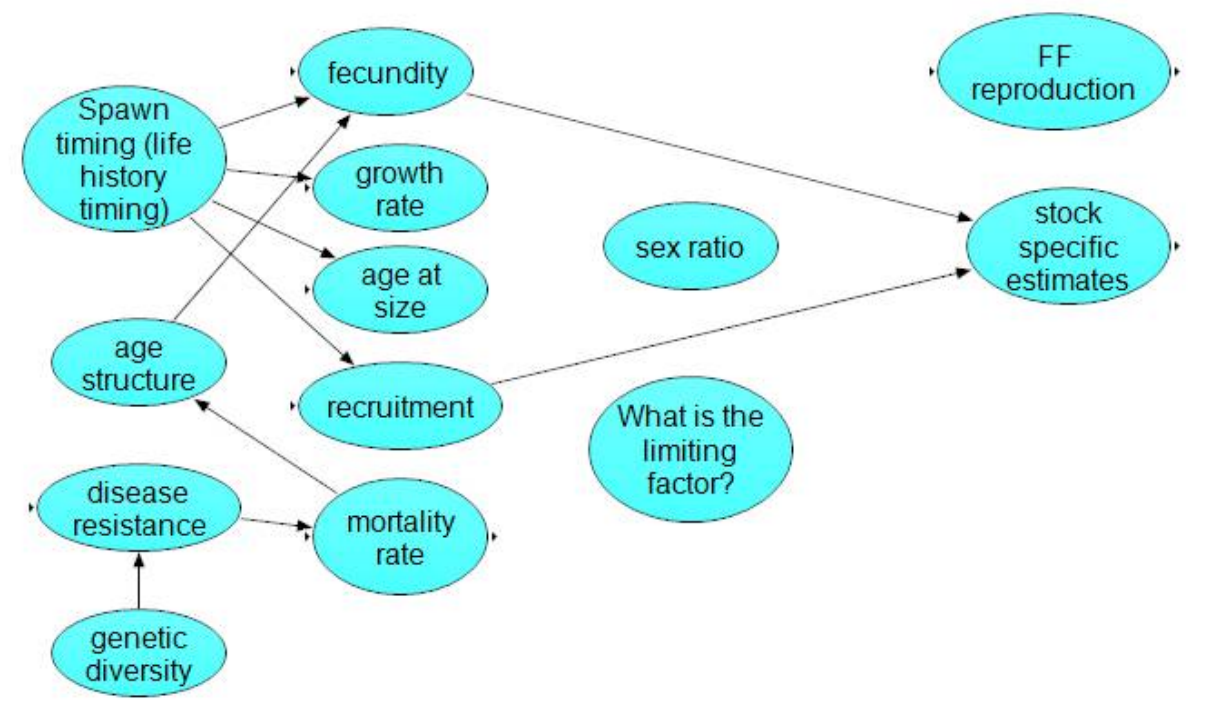

$F F=$ forage fish

Figure 3.2. Forage fish life (FF) history parameters submodel of the influence diagram created to describe effects of climate change on valued resources and management tools (fig. 3.1). The diagram summarizes the workshop discussion and is not intended to be a comprehensive representation of all possible factors and relationships. 


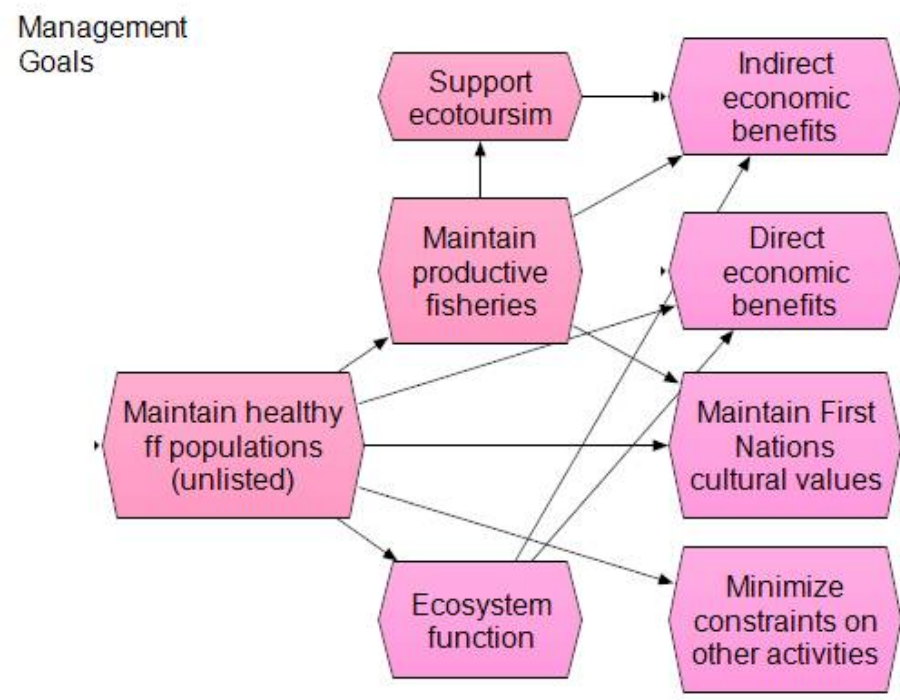

Minimize non-

native species?

Manage with common goals ecosystem management

Figure 3.3. Maintain healthy forage fish populations submodel of the influence diagram created to describe effects of climate change on valued resources and management tools (fig. 3.1). This submodel defines the management goals discussed for forage fish and shows the linkages between them. The diagram summarizes the workshop discussion and is not intended to be a comprehensive representation of all possible factors and relationships. 


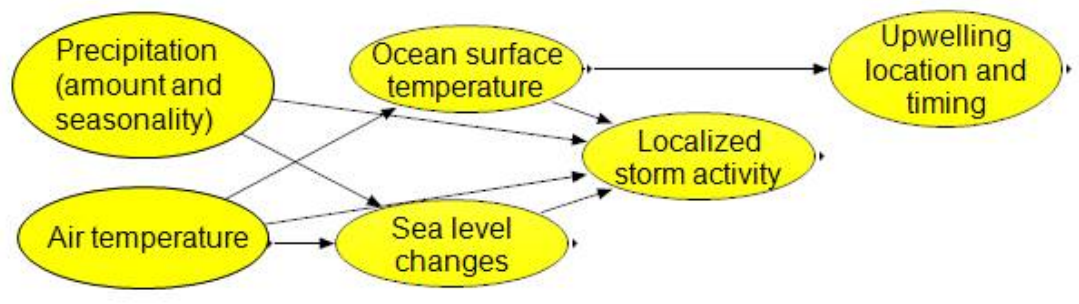

Figure 3.4. Climate submodel of the influence diagram created to describe effects of climate change on valued resources and management tools (fig. 3.1). The diagram summarizes the workshop discussion and is not intended to be a comprehensive representation of all possible factors and relationships. 


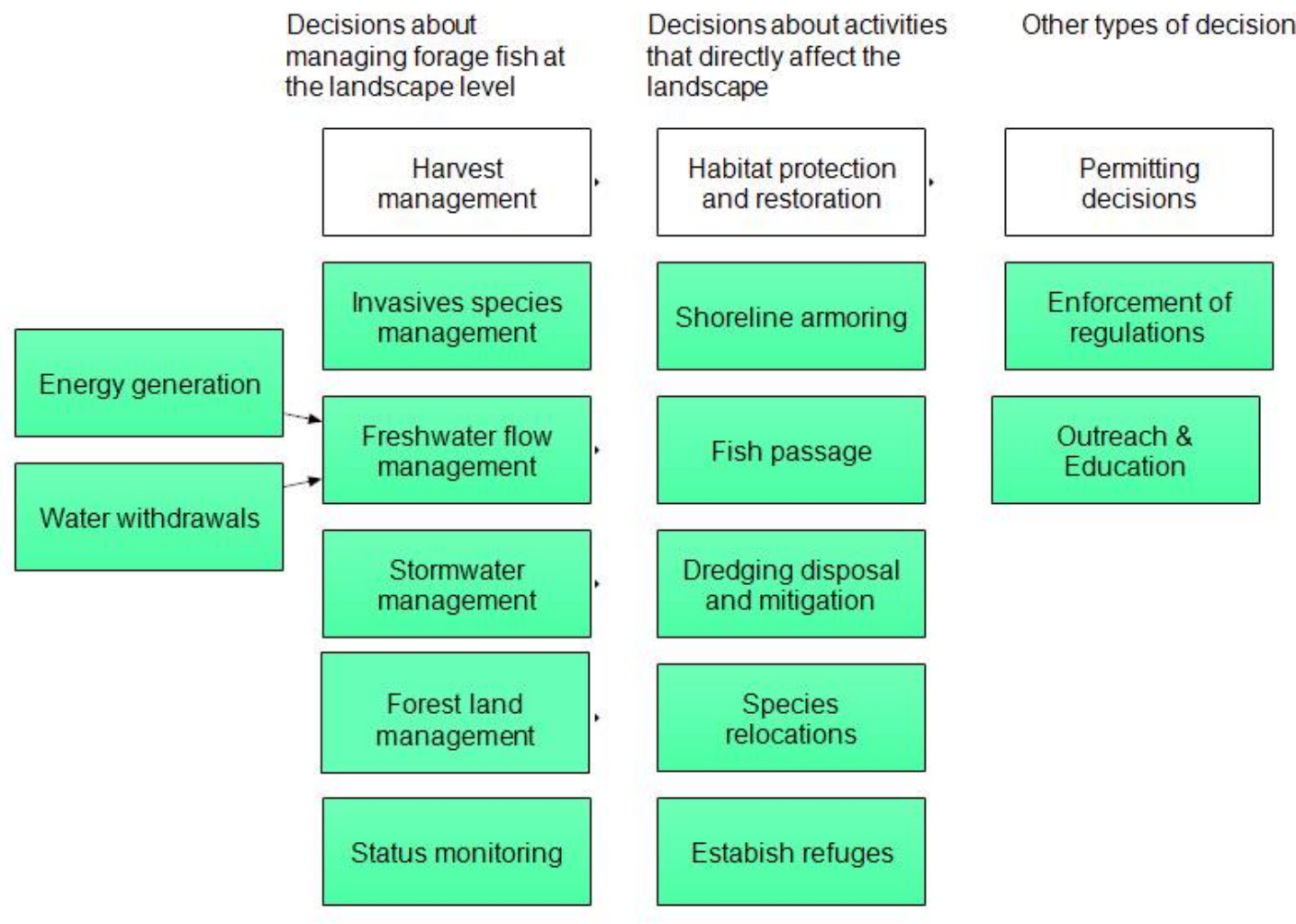

Figure 3.5. Management decisions submodel of influence diagram created to describe effects of climate change on valued resources and management tools (fig. 3.1). The diagram summarizes the workshop discussion and it not intended to be a comprehensive representation of all possible factors and relationships. 
Table 3.1. Forage fish resources within the North Pacific Landscape Conservation Cooperative (NPLCC).

\begin{tabular}{|l|l|}
\hline \multicolumn{1}{|c|}{ Species } & \multicolumn{1}{c|}{ Distribution within the NPLCC } \\
\hline Pacific herring (Clupea pallasii) & Throughout the region \\
\hline Sand lance (Ammodytes hexapterus) & Throughout the region \\
\hline Surf smelt (Hypomesus pretiosus) & Throughout the region; less important in Alaska \\
\hline Longfin smelt (Spirinchus thaleischthys) & Oregon, Washington, and California outer coast; Salish Sea \\
\hline Whitebait smelt (Allosmerus elongates) & $\begin{array}{l}\text { Oregon and Washington outer coast; possibly lower British } \\
\text { Columbia }\end{array}$ \\
\hline Night smelt (Spirinchus starksi) & $\begin{array}{l}\text { Oregon and Washington near-shore coast; possibly lower British } \\
\text { Columbia }\end{array}$ \\
\hline Delta smelt (Hypomesus transpacificus) & California (State and Federal listings as Endangered) \\
\hline Topsmelt (Atherinops affinis) & Oregon and California offshore areas \\
\hline Northern anchovy (Engraulis mordax) & Washington, Oregon, California, and lower British Columbia \\
\hline Eulachon (Thaleichthys pacificus) & Throughout the region (some stocks listed as Threatened) \\
\hline Pacific sardine (Sardinops sagax) & Washington, Oregon, California, and lower British Columbia \\
\hline Stickleback (Gasterosteus aculeatus) & Throughout the region \\
\hline Capelin (Mallotus villosus) & Alaska and northern British Columbia \\
\hline Mackerel (Scomber japonicas) & Oregon, California, and parts of Washington \\
\hline
\end{tabular}


Table 3.2. Management goals for forage fish.

\begin{tabular}{|c|c|}
\hline Management goal & Description and details \\
\hline Maintain healthy forage fish populations & $\begin{array}{ll}\text { - } & \text { Maintain stock diversity (within and among species) } \\
\text { - } & \text { Avoid Endangered Species Act listing/protection } \\
\end{array}$ \\
\hline Ecosystem function & $\begin{array}{l}\text { - Maintain ecosystem services } \\
\circ \quad \text { Food supply for other fisheries } \\
\circ \quad \text { Timing of food availability for other species } \\
\text { - Maintain species, age class, and genetic diversity } \\
\text { - } \quad \text { Avoid Endangered Species Act listing/protection } \\
\text { - Manage species interactions } \\
\circ \quad \text { Manage timing of hatchery-reared species to balance } \\
\text { prey available to predators }\end{array}$ \\
\hline Direct economic benefits & $\begin{array}{l}\text { - Harvest forage fish directly (commercial/recreational) } \\
\text { - } \quad \text { Manage harvest for sustainability of fisheries } \\
\text { - } \quad \text { Food supply for non-forage fish fisheries }\end{array}$ \\
\hline Indirect economic benefits & $\begin{array}{c}\text { - Support ecotourism } \\
0 \text { Whale watching, birding, kayaking }\end{array}$ \\
\hline Maintain First Nations cultural values & $\begin{array}{l}\text { - More valuable than simple consumption } \\
\text { - Tribal traditions based on harvest (for example, eulachon) }\end{array}$ \\
\hline Minimize constraints on other activities & $\begin{array}{l}\text { - Forage fish abundance and habitat needs may limit other } \\
\text { commercial activities (for example, oyster growers) } \\
\text { Effective management of forage fish reduces these } \\
\text { constraints }\end{array}$ \\
\hline Minimize non-native species & $\begin{array}{l}\text { - Shad throughout the range of eulachon may contribute to } \\
\text { declining abundance } \\
\text { - Unknown effects on other forage fish species }\end{array}$ \\
\hline Manage with common goals & $\begin{array}{l}\text { - Different agencies have different mandates, but all are } \\
\text { working to manage the same resources } \\
\text { - Common goals enable effective management }\end{array}$ \\
\hline $\begin{array}{l}\text { Provide learning to support ecosystem } \\
\text { management }\end{array}$ & $\begin{array}{l}\text { - Not all agencies/managers value forage fish as part of the } \\
\text { overall ecosystem } \\
\text { - Learn more about the role of forage fish in the ecosystem in } \\
\text { order to encourage managers across agencies to consider } \\
\text { indirect economic benefits of forage fish } \\
\text { - Public education and outreach activities }\end{array}$ \\
\hline
\end{tabular}


Table 3.3. Potential management actions at the landscape level.

\begin{tabular}{|c|c|}
\hline Potential management action & Description and details \\
\hline Harvest management & $\begin{array}{l}\text { - Establishing appropriate biological thresholds that consider all } \\
\text { the risks to the stocks }\end{array}$ \\
\hline Invasive species management & $\begin{array}{l}\text { - Spartina eradication efforts } \\
\circ \text { Invasive grass found in intertidal wetlands } \\
\circ \text { Alters water and sediment circulation } \\
\circ \text { Could be beneficial to some species/life stages } \\
\circ \text { Chemical treatment for control/eradication } \\
\text { - Shad throughout the range of eulachon may contribute to } \\
\text { decreasing abundance }\end{array}$ \\
\hline Freshwater flow management & $\begin{array}{l}\text { - Influenced by energy generation needs } \\
\circ \quad \text { Tidal power development } \\
\text { - Influenced by water withdrawals } \\
\circ \quad \text { Urban water supply needs } \\
\circ \quad \text { Delta smelt in California severely affected } \\
\circ \quad \text { Industrial withdrawals } \\
\text { - Surface-water intakes can kill larvae } \\
\text { - } \\
\text { Flow management through hydroelectric dams affects quality } \\
\text { of spawning substrates }\end{array}$ \\
\hline Stormwater management & - Control and regulation of nonpoint source pollution \\
\hline Forest land management & $\begin{array}{l}\text { - Source of carbon } \\
\text { - } \quad \text { Control the types of sediments that enter waterways }\end{array}$ \\
\hline Status monitoring & $\begin{array}{l}\text { - Needs to be independent of the fishery } \\
\text { - Support for funding decisions } \\
\text { - Critical for listed species (for example, eulachon in Columbia } \\
\text { River) }\end{array}$ \\
\hline Manage species interactions & $\begin{array}{l}\text { - Some species affected by harvest on other species } \\
\text { - } \quad \text { Investigate altering fishing gear to reduce bycatch }\end{array}$ \\
\hline Aquaculture & $\begin{array}{l}\text { - Artificial propagation of important species/stocks } \\
\text { - Herring aquaculture proposed in Alaska }\end{array}$ \\
\hline
\end{tabular}


Table 3.4. Potential management actions that directly affect the landscape.

\begin{tabular}{|c|c|}
\hline Potential management action & Description and details \\
\hline Habitat protection and restoration & $\begin{array}{l}\text { - Increased development in nearshore lands } \\
\circ \quad \text { Population growth } \\
\circ \quad \text { New energy requirements (for example, tidal power) } \\
\text { - Restoration of damaged areas } \\
\circ \quad \text { Removal of dikes and bulkheads } \\
\circ \text { Creosote piling removal } \\
\text { - Use mitigation where restoration is not appropriate } \\
\text { - Preservation of non-disturbed areas }\end{array}$ \\
\hline Shoreline armoring & 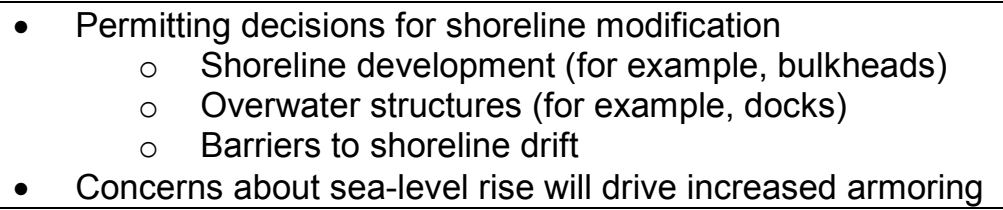 \\
\hline Fish passage & $\begin{array}{l}\text { - For anadromous species (eulachon) while in freshwater } \\
\text { - Dams block access to historical spawning grounds }\end{array}$ \\
\hline Dredging disposal and mitigation & $\begin{array}{l}\text { - Dredging activity in freshwater may entrain or kill fish if } \\
\text { conducted during the spawning season } \\
\text { - Dredge deposits can alter spawning habitat }\end{array}$ \\
\hline Species relocations & - Reintroduction of stocks to depleted areas \\
\hline Establish refuges & - Consider establishment of marine protected areas \\
\hline
\end{tabular}

Table 3.5. Potential management actions that apply to other types of decisions.

\begin{tabular}{|c|c|}
\hline Potential management action & Description and details \\
\hline Permitting decisions & $\begin{array}{l}\text { - Permit processes required for shoreline development and } \\
\text { - } \text { Nenstruction of overwater structures } \\
\text { - } \quad \text { Regulatory authority shared across many entities and is } \\
\text { - } \quad \text { applied inconsistently } \\
\text { - } \\
\text { dreedging) to reduce effects } \\
\text { - } \quad \text { Deview effects for proposed aquaculture activities } \\
\text { Devitigation actions to support permitting processes }\end{array}$ \\
\hline Enforcement of regulations & $\begin{array}{l}\text { - Current regulations are not enforced consistently } \\
\text { - Difficult to assess "significance" of effects for a proposed } \\
\text { action } \\
\text { - Identify cumulative effects to shoreline because permits are } \\
\text { issued from several sources }\end{array}$ \\
\hline Outreach and Education & $\begin{array}{l}\text { - Educate public to control effects: } \\
\circ \quad \text { Low impact shoreline building practices } \\
\circ \quad \text { Stormwater contamination of marine waters } \\
\circ \quad \text { Value of forage fish to healthy ecosystem } \\
\text { - Opportunities to collect data with industry partners } \\
\text { - Citizen science groups to assist with monitoring efforts } \\
\quad \text { Look for forage fish eggs on beaches }\end{array}$ \\
\hline
\end{tabular}


Table 3.6. Management goals, potential tools or decisions, and information needs for harvest decisions.

\begin{tabular}{|c|c|c|}
\hline Management Goals-Harvest & Tools and decisions & Information needs \\
\hline $\begin{array}{l}\text { - Maintain productive fisheries } \\
\circ \quad \text { Maintain stock diversity } \\
\circ \quad \text { Species and age class } \\
\text { diversity } \\
\circ \quad \text { Avoid Endangered } \\
\text { Species Act listing } \\
\text { - Maintain ecosystem function } \\
\text { - Maximize direct economic } \\
\text { benefits now and in the future } \\
\text { - Maximize indirect economic } \\
\text { benefits } \\
\text { - Maintain First Nations cultural } \\
\text { values }\end{array}$ & $\begin{array}{l}\text { - Establish biological } \\
\text { thresholds that consider all } \\
\text { risks to the stocks } \\
\text { - Involve ecologists in } \\
\text { harvest assessments } \\
\text { - Manage using sustainable } \\
\text { abundance compared to } \\
\text { sustainable yield } \\
\text { - Species relocations } \\
\text { - Establish refuges } \\
\text { - Artificial propagation } \\
\text { programs for critical stocks } \\
\text { o Herring culture } \\
\text { proposed in Alaska }\end{array}$ & $\begin{array}{l}\text { - Reduced uncertainty in } \\
\text { abundance estimates } \\
\text { - Projected abundance of stocks } \\
\text { over time } \\
\text { - Stock and age class specific } \\
\text { abundance and mortality } \\
\text { information } \\
\text { - Effects of reduced abundance } \\
\text { on predators (to enable } \\
\text { consideration of trade-offs) } \\
\text { - Quantify the needs of predators } \\
\text { - Limiting factor analyses: What } \\
\text { are the tolerable effects and } \\
\text { thresholds? } \\
\text { - Central database of all } \\
\text { abundance information }\end{array}$ \\
\hline
\end{tabular}

Table 3.7. Management goals, potential tools or decisions, and information needs for permitting decisions.

\begin{tabular}{|c|c|c|}
\hline Management Goal-Permitting & Tools and decisions & Information needs \\
\hline $\begin{array}{l}\text { - Maintain healthy populations of } \\
\text { forage fish } \\
\text { - Permit appropriate shoreline } \\
\text { development } \\
\text { - Maintain ecosystem function } \\
\text { - Minimize constraints on other } \\
\text { activities } \\
\text { - Manage with common goals } \\
\quad \text { Get all permitting agencies } \\
\text { working together } \\
\text { - Provide learning to support } \\
\text { ecosystem management }\end{array}$ & $\begin{array}{l}\text { - Manage development in } \\
\text { nearshore areas } \\
\quad \text { Population growth } \\
\circ \quad \text { Sea level rise } \\
\quad \text { New energy } \\
\text { demands } \\
\text { - Restoring damaged areas } \\
\text { - Preserving pristine areas } \\
\text { - Controlling timing and } \\
\text { location of dredging } \\
\text { operations } \\
\text { - Include spatial planning } \\
\text { effort in permit decisions } \\
\text { - Identify cumulative effects } \\
\text { for permits issued across } \\
\text { agencies } \\
\text { - Enforce existing } \\
\text { regulations } \\
\text { - Build a policy framework } \\
\text { that requires data } \\
\text { collection prior to permit } \\
\text { approval }\end{array}$ & $\begin{array}{l}\text { - Life history parameters for } \\
\text { species that use the shoreline } \\
\text { - Shoreline habitat requirements } \\
\text { by species and life stage } \\
\text { - Current and future locations of } \\
\text { suitable habitat } \\
\text { - Understanding of which } \\
\text { components of the habitat are } \\
\text { truly critical } \\
\text { - A "quick-guide" checklist for } \\
\text { managers: What needs to be } \\
\text { considered? } \\
\text { - Habitat maps at the community } \\
\text { level } \\
\text { - Actual (used) as compared to } \\
\text { potential (unused) shoreline } \\
\text { habitat: Current and future } \\
\text { - Spawn timing and hatch timing } \\
\text { for each species to determine } \\
\text { appropriate work windows }\end{array}$ \\
\hline
\end{tabular}


Table 3.8. Management goals, potential tools or decisions, and information needs for decisions about habitat protection.

\begin{tabular}{|c|c|c|}
\hline $\begin{array}{l}\text { Management Goal-Habitat } \\
\text { requirements and availability }\end{array}$ & Tools and decisions & Information needs \\
\hline $\begin{array}{l}\text { - Maintain productive fisheries } \\
\text { - Maintain ecosystem function } \\
\text { - Direct and indirect economic } \\
\text { benefits } \\
\text { - Maintain First Nations cultural } \\
\text { values } \\
\text { - Minimize constraints on other } \\
\text { activities } \\
\text { - Manage with common goals } \\
\text { - Provide learning to support } \\
\text { - } \text { ecosystem management } \\
\text { - Protect, preserve, or restore } \\
\text { critical habitats for forage fish } \\
\text { - Manage freshwater flow to } \\
\text { benefit forage fish } \\
\text { - Manage stormwater to benefit } \\
\text { forage fish } \\
\text { - Manage forestland } \\
\quad \text { Sediment control } \\
\text { - Mitigate dredging activity and } \\
\text { disposal }\end{array}$ & $\begin{array}{l}\text { - Establish refuges } \\
\text { - Enforce existing } \\
\text { regulations that protect } \\
\text { habitat } \\
\text { - Field studies of natural } \\
\text { history by species and life } \\
\text { stage } \\
\text { - Historical and Traditional } \\
\text { Ecological Knowledge } \\
\text { review to evaluate site } \\
\text { fidelity } \\
\text { - Review historical data on } \\
\text { prevalence and correlate } \\
\text { environmental variables } \\
\text { - Establish/maintain citizen } \\
\text { scientist monitoring efforts } \\
\text { - Collect and share existing } \\
\text { data on water temperature, } \\
\text { sediments, and so on as } \\
\text { covariates } \\
\text { - Encourage collaboration } \\
\text { on sample collection and } \\
\text { processing } \\
\text { O Use the same fish for } \\
\text { genetics, } \\
\text { contaminants, } \\
\text { fecundity, and so on }\end{array}$ & $\begin{array}{l}\text { - Basic distribution and timing } \\
\circ \quad \text { Where are they and when? } \\
\text { - Basic life stage parameters } \\
\text { - Shoreline habitat requirements } \\
\text { by species and life stage } \\
\text { - LiDAR surveys with mapping to } \\
\text { identify required habitat } \\
\text { characteristics } \\
\text { - Information on site fidelity for } \\
\text { shoreline species } \\
\text { - Information on forage fish } \\
\text { catches from commercial } \\
\text { fishing logs } \\
\text { - Sea level rise predictions and } \\
\text { their effects on beach habitats } \\
\circ \quad \text { Locally relevant } \\
\text { - Fish passage barriers for } \\
\text { anadromous species } \\
\text { (eulachon) } \\
\circ \quad \text { Spawning habitat blocked } \\
\text { - Vegetation monitoring } \\
\text { (terrestrial and marine) } \\
\text { O Changes affect habitat } \\
\quad \text { quality }\end{array}$ \\
\hline
\end{tabular}


Table 3.9. Management goals, potential tools or decisions, and information needs for management of other species.

\begin{tabular}{|c|c|c|}
\hline $\begin{array}{c}\text { Management Goal-Management of } \\
\text { other species }\end{array}$ & Tools and decisions & Information needs \\
\hline $\begin{array}{l}\text { - Minimize non-native species } \\
\text { - Minimize constraints on other } \\
\text { activities } \\
\text { - Maintain productive fisheries } \\
\text { - Maintain ecosystem function } \\
\text { - Maximize indirect economic } \\
\text { benefits }\end{array}$ & $\begin{array}{l}\text { - Management of non-native } \\
\text { species (Spartina, shad) } \\
\text { - Investigate altering fishing } \\
\text { gear to reduce bycatch } \\
\text { - Case studies of past } \\
\text { negative interactions } \\
\text { between species to } \\
\text { highlight lessons learned } \\
\text { - Consider management } \\
\text { actions specific to predator } \\
\text { congregation "hot spots" }\end{array}$ & $\begin{array}{l}\text { - Best practices for bycatch } \\
\text { reduction } \\
\text { ○ Washington shrimp trawl } \\
\text { fishery catches eulachon } \\
\text { - What other forage fish species } \\
\text { are at risk of bycatch in } \\
\text { fisheries? } \\
\circ \quad \text { Commercial log survey } \\
\text { - Do shad pose a risk to } \\
\text { eulachon? } \\
\text { - Diet studies of predators } \\
\circ \quad \text { How much prey switching } \\
\text { occurs? What is their true } \\
\text { reliance on forage fish? } \\
\text { - Consequences of phenology of } \\
\text { forage fish availability on other } \\
\text { species } \\
\text { Nesting migratory birds } \\
\text { - Climate-induced changes on } \\
\text { predator species } \\
\text { Distribution, numbers, } \\
\text { timing } \\
\text { - Are there predator } \\
\text { congregation "hot spots" where } \\
\text { special protection/management } \\
\text { actions could be useful? }\end{array}$ \\
\hline
\end{tabular}




\section{Chapter 4. Lessons Learned}

\section{Unique Role of North Pacific Landscape Conservation Cooperative in Addressing Management Needs}

LCCs have a unique mandate that crosses international and jurisdictional boundaries to meet the needs of resource managers regarding a wide range of information products in addition to scientific research. Both workshops highlighted a lack of understanding of the cumulative effects on valued natural resources. Although individual agencies are focused within their own boundaries, decisions may have landscape and regional consequences with effects on neighboring agencies, making the consideration and communication of cumulative effects a potentially important role for the NPLCC. The need for landscape and broader-scale resource management in the age of climate change motivated the establishment of LCCs, and they are distinctively charged to accumulate and disseminate resource conditions at large spatial scales.

LCCs are designed to be management-research partnerships, so in addition to supporting research, they also can address the need for outreach, education, and management tools. Specific needs identified during the workshops include conveying to the public and others the importance of noncharismatic resources in particular; the potential effects of climate change; and the consequences and trade-offs involved in management decisions and societal choices. An example of a potentially valuable information tool for managers was described as a permitting guide checklist during the forage fish workshop. This tool would help managers decide where best to protect and restore shoreline resources based on locally described considerations.

Finally, several over-arching and general information needs to support management decisions were identified during the workshops:

- What are the appropriate spatial and temporal scales for various types of decisions and resources?

- How does one assign a value to non-marketable attributes and properties? This may apply to resources with traditional and cultural uses; experiences and beliefs; and ecological roles, such as importance in a food web, among other properties.

- How much information is enough to make a decision? Between the uncertainties about the future and incomplete knowledge of resources, how much information meets the minimum requirement for a responsible decision? How can that be defined?

- How should managers incorporate unanticipated changes and unintended consequences into their decisions and planning? 


\section{Potential Role of Traditional Ecological Knowledge}

During the forage fish workshop, participants recognized that there may be TEK about the historical distribution and abundance of forage fish, and that TEK also could be an important contributor to improving understanding of life history parameters, habitat needs, and the response of forage fish population to historical stresses. The NPLCC and other entities interested in pursuing this work should be encouraged to work with interested Tribes and First Nations to determine their ability and interest in collecting and contributing such TEK. In addition, many forest resources have cultural value for native cultures, and there may be TEK that would help clarify the various information needs identified in the workshop. The forest resources workshop also highlighted a challenge associated with the use of TEK in management decision-making, which is the sensitive and proprietary nature of some TEK, particularly place-based information about important forest-related cultural resources.

\section{Conduct of Workshops}

One-day workshops were an effective way to gather information needs relevant to potential management decisions from resource managers. In addition to information needs related to specific management decisions, managers also identified overarching questions that the NPLCC uniquely may be able to address and how information might be packaged to be most useful. Several areas of improvement for future workshops were identified:

- Workshops with more tightly focused topics, such as forage fish, yield more specific and immediately useful information needs than those with broad topics such as forest resources. Although the LCCs were designed to be ecologically cohesive areas, there is enough subregional variation that it is difficult to comprehensively discuss even a narrow topic across the entire LCC in 1 day. Finding the appropriate level of geographic and topical focus for a highly productive 1day workshop requires careful consideration and is critical to producing timely useful outcomes.

- It is useful to be able to build on recent work during the workshop, as was done during the forage fish workshop. Being able to present the results from a recent research symposium helped quickly unify the group around a common understanding of the issues. It also is possible, however, that anchoring the participants on recent work prevented them from thinking as broadly about the topic as would be useful.

- The use of decision analysis techniques provided a strong structure for the workshops, and helped the participants work through an aggressive schedule and the questions most relevant to the NPLCC in a short period of time. The use of an influence diagram to record ideas and problem structure in real-time during the discussions was particularly useful in the second workshop. Compared to the first workshop, the second workshop benefited from the recent (September 2012) forage fish research symposium (so a conceptual model structure existed from the start), from a group of participants who were immediately comfortable with the structure as a conceptual modeling tool, and from better logistics and display technologies so that the entire group could see and contribute to the influence diagram as it was developed. Because this tool is new to many managers, they may require some time to understand it and to use it effectively. 


\section{References Cited}

Baumgartner, T.R., Soutar, A., and Ferreira-Bartrina, V., 1992, Reconstruction of the history of Pacific sardine and northern anchovy populations over the past two millennia from sediments of the Santa Barbara Basin, California: California Cooperative Oceanic Fisheries Investigations Report, v. 33, p. 24-40.

Caro, T., 2010, Conservation by proxy: indicator, umbrella, keystone, flagship and other surrogate species: Island Press, Washington, D.C., 374 p.

Curry, P., Bakun, A., Crawford, R.J.M, Jarre, A., Quinones, R.A., Shannon, L.J., and Verheye, H.M., 2000, Small pelagics in upwelling systems: Patterns of interaction and structural changes in "waspwaist" ecosystems: ICES Journal of Marine Science, v. 57, p. 603-618.

Grebmeier, J.M., Overland, J.E., Moore, S.E., Farley, E.V., Carmack, E.C., Cooper, L.W., Frey, K.E., Helle, J.H., McLaughlin, F.A., and McNutt, S.L., 2006, A major shift in the northern Bering Sea: Science, v. 311, p. 1461-1464.

Hannah, R.W., Jones, S.A., Lomeli, M.J.M., and Wakefield, W.W., 2011, Trawl net modifications to reduce the bycatch of eulachon (Thaleichthys pacificus) in the ocean shrimp (Pandalus jordani) fishery: Fisheries Research, v. 110, p. 277-282.

Hershberger, P.K., van der Leeuw, B.K., Gregg, J.L., Grady, C.A., Lujan, K.M., Gutenberger, S.K., Purcell, M.K., Woodson, J.C., Winton, J.R., and Parsley, M.J., 2010, Amplification and transport of an endemic fish disease by an introduced species: Biological Invasions, v. 12, p. 3665-3675.

Howard, R.A., and Matheson, J.E., 2005, Influence diagrams: Decisions Analysis, v. 3, p. 127-143.

Jenni, K., Shipley, F., and Mahaffy, M., 2012, Strategy for science-traditional ecological knowledge, 2013-2016 (Version 1.0): Lacey, Washington, North Pacific Landscape Conservation Cooperative, 19 p., accessed September 8, 2013, at http://northpacificlcc.org/Documents/S-

TEK\%20Strategy_Final_11-2012.pdf.

Keefer, D. L., Kirkwood, C.W., and Corner, J.L., 2004, Perspective on decision analysis applications, 1990-2001: Decision Analysis, v. 1, p. 5-24.

Liedtke, T., Gibson, C., Lowry, D., and Fagergren, D., eds., 2013, Conservation and ecology of marine forage fishes-Proceedings of a research symposium, September 2012: U.S. Geological Survey Open-File Report 2013-1035, 24 p.

Littell, J.S., Oneil, E.E., McKenzie, D., Hicke, J.A., Lutz, A.A., Norheim, R.A., and Elsner, M.M., 2010, Forest ecosystems, disturbance and climatic change in Washington State, USA: Climatic Change, v. 102, p. 129-158.

Luce, C., Morgan, P., Dwire, K., Isaak, D., Holden, Z., and Rieman, B., 2012, Climate change, forests, fire, water and fish: Building resilient landscapes, streams, and managers. U.S. Department of Agriculture Forest Service Rocky Mountain Field Station General Technical Report RMRS-GTR-290.

McKenzie, D., Gedalof, Z., Peterson, D.L., and Mote, P., 2004, Climatic change, wildfire, and conservation: Conservation Biology, v. 18, p. 890-902. 
Mote, P.W., Parson, E.A., Hamlet, A.F., Keetong, W.S., Lettenmaier, D., Mantua, N., Miles, E.L., Peterson, D.W., Peterson, D.L., Slaughter, R., and Snover, A.K., 2003, Preparing for climatic change-The water, salmon and forests of the Pacific Northwest: Climatic Change, v. 61, p. 45-88.

Mueter, F.J., and Litzow, M.A., 2008, Sea ice retreat alters the biogeography of the Bering Sea continental shelf: Ecological Applications, v. 18, p. 309-320.

North Pacific Landscape Conservation Cooperative, undated, North pacific landscape conservation cooperative charter, http://northpacificlcc.org/NPLCC_Charter.pdf.

Partridge, C., and MacGregor, B., 2007, The future of Washington forests: Washington State Department of Natural Resources, Olympia, Washington.

Pearl, J., 2005, Influence diagrams-Historical and personal perspectives: Decision Analysis, v. 2, p. 232-234.

Pikitch, E., Boersma, P.D., Boyd, I.L., Conover, D.O., Cury, P., Essington, T., Heppell, S.S., Houde, E.D., Mangel, M., Pauly, D., Plagányi, É., Sainsbury, K., and Seneck, R.S., 2012, Little fish, big impact: managing a crucial link in ocean food webs: Lenfest Ocean Program, Washington, DC, 108 p.

Smith, A.D.M., Brown, C.J., Bulman, C.M., Fulton, E.A., Johnson, P., Kaplan, K.C., Lozano-Montes, H., Mackinson, S., Marzloff, M., Shonnon, Y.-J., and Tam, J., 2011, Impacts of fishing low-trophic level species on marine ecosystems: Science, v. 333, p. 1147-1150.

Stephens, S.L., McIver, J.D., Boerner, R.E.J., Fettig, C.J., Fontaine, J.B., Hartsough, B.R., Kennedy, P.L., and Schwilk, D.W., 2012, The effects of forest fuel-reduction treatments in the United States: Bioscience, v. 62, p. 549-560.

U.S. Department of Interior, U.S. Department of Agriculture, Department of Energy, Department of Defense, Department of Commerce, U.S. Environmental Protection Agency, Federal Emergency Management Agency, and National Association of State Foresters, 2001, Review and update of the 1995 federal wildland fire management policy: National Interagency Fire Center, Boise, Idaho.

U.S. Fish and Wildlife Service, 2012, Draft guidance on selecting species for design of landscape-scale conservation, http://www.fws.gov/landscape-conservation/pdf/drafttechnicalguidancejuly2012.pdf.

Wang, M., Overland, J.E., and Bond, N.A., 2010, Climate projections for selected large marine ecosystems: Journal of Marine Systems, v. 79, p. 258-266. 


\section{Appendix 1. Forest Meeting Participants}

\begin{tabular}{|l|l|}
\hline \multicolumn{1}{|c|}{ Name } & \multicolumn{1}{c|}{ Affiliation } \\
\hline Steve Acker & National Park Service, Olympic National Park \\
\hline Timothy Ebata & $\begin{array}{l}\text { British Columbia Ministry of Forests Lands and Natural Resource Operations, Resources Practices } \\
\text { Branch }\end{array}$ \\
\hline Eamon Engber & National Park Service, Redwoods National Park \\
\hline Michael Goldstein & U.S. Forest Service, Alaska Rainforest Center \\
\hline Karen Jenni & Insight Decisions, LLC \\
\hline David Kendrick & U.S. Forest Service, Mount Baker Snoqualmie National Forest (Washington) \\
\hline Howard Kuljian & U.S. Forest Service, Six Rivers National Forest (California) \\
\hline Theresa Liedtke & U.S. Geological Survey, Western Fisheries Research Center \\
\hline Mary Mahaffy & North Pacific Landscape Conservation Cooperative \\
\hline Don McKenzie & $\begin{array}{l}\text { U.S. Forest Service Pacific Northwest Research Center, University of Washington Climate Impacts } \\
\text { Group }\end{array}$ \\
\hline Gary Morishima & Quinault Indian Tribe and Inter-tribal Timber Council \\
\hline William Vogel & U.S. Fish and Wildlife Service, Washington Fish and Wildlife Office \\
\hline Andrea Woodward & U.S. Geological Survey, Forest and Rangeland Ecosystem Science Center \\
\hline
\end{tabular}




\section{Appendix 2. Forest Resources Workshop Agenda \\ Effects of Climate Change on Forest Resources of the North Pacific Landscape \\ Conservation Cooperative (NPLCC) -November 20, 2012 U.S. Geological Survey, Western Fisheries Research Center, Seattle, Washington}

\author{
8:30-8:50 a.m. \\ 8:50-10:00 a.m.
}

10:00-10:15 a.m. Break

10:15-10:30 a.m.

10:30 am-12:00 p.m.

12:00-1:00 p.m.

$1: 00-2: 30$ p.m.

$2: 30-2: 45 \mathrm{pm}$

2:45-4:00 p.m.

4:00-4:30 p.m.
Introduction to NPLCC, Meeting Goals, and Process

Identify valued forest resources, services and related management goals. Consider:

- Specific forest resources, their locations within the NPLCC, and entities with forestmanagement related responsibilities or interests for those resources

- Benefits and services those resources provide

- Any key differences in management goals by agency or differences in interests among stakeholders

Summary of climate-related stressors on forest resources

- Climate change projections and scenarios

- Projected changes in demand for services

Discuss potential effects of climate-related changes on the valued forest resources and services identified. Consider:

- What climate-related factors will affect each of the various resources and services?

- What are the important physical, biological, social and economic interactions among these factors and resources?

- Do / how do these relationships differ across the NPLCC geography?

- How much is known or not known about these relationships?

Lunch (will bring in box lunches)

Identify and discuss potential management actions to respond to effects of climate-related stressors. Consider:

- What types of management actions can various stakeholders take?

- How can those actions affect management outcomes?

- How does climate change impact the effectiveness of different management options?

Break

Review conceptual model and identify decision-relevant information needs. Consider:

- Key relationships identified previously and the current level of knowledge/uncertainty in those relationships

- How resolution of those uncertainties might affect decisions

- What activities might be undertaken to generate the identified information needs Identify sources of information that already exist to support potential management actions 


\section{Appendix 3. Forage Fish Workshop Participants}

\begin{tabular}{|l|l|}
\hline \multicolumn{1}{|c|}{ Name } & \multicolumn{1}{c|}{ Affiliation } \\
\hline Hannah Barrett & Port Gamble S'Klallam Tribe \\
\hline Nicholas Bond & Washington State Climatologist, University of Washington \\
\hline Karin Bumbaco & Assistant Washington State Climatologist \\
\hline Raquel Crosier & Northwest Power and Conservation Council \\
\hline Paul Dorn & Suquamish Tribe \\
\hline Duane Fagergren & Puget Sound Partnership \\
\hline Steven Fradkin & National Park Service Olympic National Park \\
\hline Joseph Gilbertson & Hoh Tribe \\
\hline Correigh Greene & National Oceanic and Atmospheric Administration Fisheries Northwest Fisheries Science Center \\
\hline Jennifer Hagen & Quileute Tribe \\
\hline Kyle Hebert & Alaska Department of Fish and Game \\
\hline Karen Jenni & Insight Decisions, LLC \\
\hline Theresa Liedtke & U.S. Geological Survey Western Fisheries Research Center \\
\hline Mary Mahaffy & North Pacific Landscape Conservation Cooperative \\
\hline Steven Marx & Pew Environment Group \\
\hline Craig Olds & Cowlitz Tribe \\
\hline Cyreis Schmitt & Oregon Department of Fish and Wildlife \\
\hline Lorna Wargo & Washington State Department of Fish and Wildlife \\
\hline Andrea Woodward & U.S. Geological Survey Forest and Rangeland Ecosystem Science Center \\
\hline
\end{tabular}




\section{Appendix 4. Forage Fish Workshop Agenda \\ Effects of Climate Change on Forage Fish Resources of the \\ North Pacific Landscape Conservation Cooperative (NPLCC)}

Workshop Goals:

January 31,2013

(1) Develop a list of forage fish resources within the NPLCC.

(2) List potential climate-related impacts to these resources.

(3) List potential management actions that could be used to mitigate climate-related impacts.

(4) Identify the current state of knowledge and information gaps that might affect the ability

to enact management actions.

(5) Summarize the group discussions in a conceptual framework that clarifies linkages.

8:00 a.m. Coffee and breakfast snacks available

8:30-8:50 a.m. Introduction to NPLCC, meeting goals, and workshop process

8:50-9:00 a.m. Summary of recent forage fish research symposium and identified priority research and management actions.

9:00-10:00 a.m. Identify valued forage fish resources and services and related management goals. Consider:

- The location of specific forage fish resources within the NPLCC

- Benefits and services those resources provide

- Any key differences in management goals by different stakeholders

- Any key differences in resources across the NPLCC gradient

10:00-10:15 a.m. Break

10:15-10:30 a.m. Summary of potential climate-related stressors on forage fish resources

- Climate change projections and scenarios

10:30-11:30 a.m. Discuss potential effects of climate-related changes on the valued forage fish resources and services identified.

Consider:

-What climate-related factors will affect each of the resources?

- What are the main physical, biological, social, and economic interactions among these factors and the valued resources?

- Do these relationships differ across the range of NPLCC?

- How much is known about these relationships?

11:30-Noon Identify and discuss potential management actions that may be used to respond to the effects of climate-related stressors.

-What types of management actions can stakeholders take?

- How can those actions affect management outcomes?

- How do climate change impacts influence the effectiveness of different management options? 
Noon-12:45 p.m. Lunch (box lunches will be available)

12:45-2:30 p.m. Continue discussion of potential management actions.

- Of the potential actions, which are most likely to be used?

- Of the potential actions, which are most "significant"?

2:30-2:45 p.m. Break

- Select a subset of priority management actions to investigate further.

2:45-4:00 p.m. Identify information needs to enable the identified priority management actions. Consider:

-What uncertainties prevent or limit enactment of key management actions?

- How would resolution of those uncertainties affect management decisions?

-What activities might be undertaken to generate the information needed?

4:00-4:30 p.m. Identify sources of information that already exist to support priority management actions.

Following the workshop, a draft of the summary will be circulated for review and additional input. 
Publishing support provided by the U.S. Geological Survey Publishing Network, Tacoma Publishing Service Center

For additional information contact:

Director, Forest and Rangeland Ecosystem Science Center U.S. Geological Survey

777 NW 9th St., Suite 400

Corvallis, Oregon 97330

http://fresc.usgs.gov/ 


\section{हू}

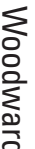

일

믐

寄

吾

을

굥

$\frac{10}{0}$

家

늘

7

굴

를

\$

₹ 